1

2

\section{Vertebrate remains from the Upper Cretaceous (Santonian) Ajka Coal}

\section{Formation, western Hungary}

3

4 Attila Ösi ${ }^{\mathrm{a}, *}$, Emese Réka Bodor ${ }^{\mathrm{b}, \mathrm{c}}$, László Makádi ${ }^{\mathrm{b}, \mathrm{c}, \mathrm{d}}$, Márton Rabi ${ }^{\mathrm{a}, \mathrm{e}}$

5 a MTA-ELTE Lendület Dinosaur Research Group, Pázmány Péter sétány 1/c, Budapest 1117, Hungary

$6 \quad{ }^{\mathrm{b}}$ Geological and Geophysical Institute of Hungary, Stefánia út 14, Budapest 1143, Hungary

$7 \quad{ }^{\mathrm{c}}$ Eötvös University, Department of Paleontology, Pázmány Péter sétány 1/c, Budapest, 1117, Hungary

$8{ }^{\mathrm{d}}$ Hungarian Natural History Museum, Ludovika tér 2, Budapest 1083, Hungary

$9{ }^{\mathrm{e}}$ University of Tübingen, Institute of Geosciences, Sigwartstraße 10, 72070 Tübingen, Germany

*Corresponding author.

E-mail address: hungaros@gmail.com (A. Ösi)

\section{Highlights:}

Continental vertebrates from Upper Cretaceous swamp deposits are described.

2 These fossils reveal taxonomical overlapping with those from alluvial sediments.

3 Ankylosaurs preferred wetland habitats such as fluvial systems and coastal regions. 
A B S T R A C T

Vertebrate remains from the Upper Cretaceous (Santonian) Ajka Coal Formation (Bakony

Mountains, western Hungary) are described. Macro- and microfossils collected from two

boreholes and from isolated chunks of sediment/matrix dumped on spoil heaps of the Jókai

Mine represent pycnodontiform and lepisosteiform fishes, bothremydid turtles, the mosasauroid Pannoniasaurus inexpectatus, the crocodyliforms cf. Theriosuchus,

34 Iharkutosuchus makadii and cf. Allodaposuchus, as well as ankylosaurian and theropod dinosaurs. This unit was deposited in a swampy lacustrine environment, in contrast with the neighbouring and contemporaneous floodplain deposit of the vertebrate-bearing Csehbánya Formation at Iharkút. Despite significant environmental differences, the faunal composition of the Ajka Coal Formation assemblage completely overlaps with that of the Csehbánya Formation, suggesting the occurrence of the same semi-aquatic and terrestrial species in both settings. The ankylosaurian remains further strengthen the previous view that ankylosaurs preferred wetland habitats such as fluvial systems and coastal regions.

Keywords:

Late Cretaceous

Continental vertebrates

Swampy environment

Dinosaurs

Hungary 


\section{Introduction}

Vertebrate remains from the Mesozoic of Hungary are relatively rare and aside from a few isolated (occasionally articulated) remains only two localities are known to provide systematically collectable assemblages. In geochronological order, the first one is situated at Villány (Villány Hills, southwestern Hungary), and includes two outcrops of the Middle Triassic (Ladinian) Templomhegy Dolomite Member (Csukma Dolomite Formation) and the Upper Triassic (Carnian) Mészhegy Sandstone Formation. Recent systematic excavations and screen-washing of the fossiliferous beds have resulted in both macro- and microfossils of different groups of marine vertebrates (Ösi et al., 2014). The second locality is the Upper Cretaceous (Santonian) Iharkút (Bakony Mts, western Hungary) where excavations of the bone-bearing horizons of the Csehbánya Formation have yielded a diverse and rich continental-freshwater fauna during the past 14 years (Ösi et al., 2012).

Prior to the discovery of the Iharkút locality in 2000 , some isolated bones and teeth were already known from the Upper Cretaceous Ajka Coal Formation (deposited roughly contemporaneously with the Csehbánya Formation), suggesting the potential for finding vertebrate-bearing horizons within the unit. Most of these specimens, however, were found by chance during the 140 years of underground coal mining activities (started in 1865) in the Ajka-Felső-Csinger-Gyepükaján Zone.

The first mention of a vertebrate fossil from the Ajka Coal Formation was made by Leopold Tausch (1886: 26), who presented merely a short note on a 'small reptile or fish tooth fragment' in his detailed review on the molluscan fauna of the Ajka coal beds.

Unfortunately, most of the type specimens of the different molluscan species (Bandel and Riedel, 1994) or the precise location of this tooth cannot be identified.

The next discoveries of vertebrates in the Ajka coal beds was linked to extensive exploration drilling by the coal and bauxite mining industries in the area during the 1980s. 
Various specimens were collected from cores and deposited in the collections of the

Geological and Geophysical Institute of Hungary (MFGI, formerly Hungarian Geological Institute: MÁFI), but these have never been studied in detail. In 2013, due to rearrangement of the MFGI vertebrate collections, some specimens and pieces of bone-bearing cores were brought to the attention.

During the search for Cretaceous vertebrates in the Bakony Mountains in 1999 and 2000, the first specimens discovered were isolated fish and crocodilian teeth and a few bone fragments from the Upper Cretaceous (Santonian) Ajka Coal Formation. These specimens were recovered either by breaking up chunks of coal-bearing matrix dumped on spoil heaps of the Ajka collieries or collected by screen-washing these rocks. Recently, more screen-washing of approximately $60 \mathrm{~kg}$ of matrix collected in 2012 from these spoil heaps was conducted, yielding most of the microvertebrate remains described here.

In the present paper, we record these fragmentary but taxonomically important vertebrate fossils and discuss their palaeoecological implications in the light of vertebrate faunas of the contemporaneous Csehbánya Formation at Iharkút.

\section{Localities and geological setting}

\subsection{Localities}

Vertebrate remains from the Ajka Coal Formation have been collected from cores of the Káptalanfa-2 (from 803 m; final depth: 847.8 m) and Gyepükaján-12 (from 473 m; final depth: $606.3 \mathrm{~m}$ ) boreholes, and from chunks of matrix dumped on spoil heaps of the Jókai

Mine near Ajka-Alsó-Csinger (co-ordinates: N 47 04’31”, E $17^{\circ} 33^{\prime} 55^{\prime \prime}$; see Fig. 1).

Today, these spoil heaps have been excavated and overgrown, which means that extensive collecting of fossils has become much more difficult. 
Although natural outcrops of the Ajka Coal Formation are extremely rare, a few sites

(e.g., along the Bocskor Trench) and thin coal beds along the Csinger Valley between Ajka and Úrkút initiated a search for coal which led to the first mining activities in the area during the 1860s (Kozma, 1991).

\subsection{Geological setting}

As is typical in many parts of the Transdanubian Range, Upper Triassic rocks or, more rarely, Jurassic cherty limestone or Lower Cretaceous limestones, form the basement of Upper Cretaceous transgressive sequences (Figs. 1C, 2). During the early Late Cretaceous 112 bauxites formed in the uneven karstic traps of the Triassic Dachstein Limestone and 113 Hauptdolomit Formations (Haas and Jocha Edelényi, 1979). In some parts of the Bakony 114 Mountains, bauxites and karstic palaeosurfaces were covered by the contemporaneous 115 Csehbánya and Ajka Coal Formations during the Santonian. The two units are heterotopic 116 facies being lateral equivalents with interfingered beds (Fig. 3) in the eastern part of the 117 depositional environment. On the other hand, in the western part the Csehbánya Formation 118 became a relatively thin unit superposed by the much thicker Ajka Formation (Fig. 2). The 119 Csehbánya Formation is a floodplain unit that consists mainly of variegated clays, palaeosols 120 and silt, with sand and sandstone layers (Jocha-Edelényi, 1988). Whereas this formation is 121 typically thin or even absent in the western part of the basin, it does reach a thickness between 12250 and $200 \mathrm{~m}$ more easterly (Pápa-Csehbánya Zone). At the Iharkút vertebrate locality, the 123 Csehbánya Formation contains various fossiliferous layers, including a well-known 124 continental vertebrate assemblage of over 10,000 specimens belonging to at least 35 taxa (see 125 Ösi et al., 2012; Botfalvai et al., 2015).

The main depositional area of the Ajka Coal Formation was situated to the west-south127 west of that of the Csehbánya Formation, and it was dominated by swampy and lacustrine 
environments in at least three different carbonate terrain subbasins (Ajka, Magyarpolány-

129 Devecser and Gyepükaján) (see Császár and Góczán, 1988; Siegl-Farkas, 1988). In the area of 130 Ajka and Gyepükaján, the relatively thin sequences of the Csehbánya Formation are overlain 131 by the Ajka Coal Formation (Fig. 2). In contrast to the predominantly fluvial, alluvial 132 lithofacies of the Csehbánya Formation, the Ajka Coal Formation comprises an alternation of 133 lignite beds, marls, sands and sandstone beds, and grey to brownish carbonaceous to 134 argillaceous pelitic sediments with interbedded molluscan lumachelles (Haas, 1983) and 135 represents a lacustrine-palustrine sequence. Whereas the Ajka Coal Formation is over $110 \mathrm{~m}$ 136 thick in the Gyepükaján area (e.g., Gyepükaján-10 and Káptalanfa-2 boreholes; see Fig. 2), it 137 wedges out in the area of Magyarpolány and is absent at Iharkút. The Csehbánya Formation 138 and most of the Ajka Coal Formation were laid down in freshwater environments and their 139 age is Santonian on the basis of palynological and nannoplankton studies (Siegl-Farkas and 140 Wagreich, 1996; Bodor and Baranyi, 2012; Bodrogi et al., 1998; see Fig. 3). Whereas the 141 lacustrine, peat-fen environment of the Ajka Coal Formation generally grades into the marine 142 Jákó Marl Formation (Haas et al., 1992), to the east, Upper Cretaceous rocks are mostly 143 eroded in the Ajka Subbasin and the Ajka Coal Formation is overlain by Eocene shallow144 marine limestones of the Szőc Limestone Formation.

\section{Material and methods}

Vertebrate remains from the boreholes Káptalanfa-2 and Gyepükaján-12 were discovered in the 1980s by Zoltán Partényi during examination of the cores (Fig. 4). These specimens are now housed in the collections of the Geological and Geophysical Institute of Hungary (MFGI). Whereas some specimens are still embedded in the cores and only one side can be studied, others have been freed completely from the matrix. These specimens usually 
are fragmentary, in part due the effects of drilling and in part because of the lack of preparation and conservation.

Specimens collected by our research team in 1999 and 2000, as well as material obtained by screenwashing in 2014, are housed in the collections of the Hungarian Natural History Museum (MTM). Microvertebrate remains (Fig. 5) form a significant part of the vertebrate collection from the Ajka Coal Formation; these were obtained in 2014 by screenwashing $c .60 \mathrm{~kg}$ of coal-bearing sediments, collected in 2012. In order to dissolve this matrix 20 per cent acetic acid was used. Due to the large amount of residue, consisting mainly 160 of coalified plant debris and molluscan shell fragments, saturated $\mathrm{ZnCl}_{2}$ solution was used as 161 a heavy liquid (density around $1.9 \mathrm{~g} / \mathrm{cm}^{3}$ ) to separate the dominant (approximately 80 per 162 cent) coalified plant fragments from the remainder of the residue. Approximately $200 \mathrm{~cm}^{3}$ of 163 residue was put in a $1.000 \mathrm{~cm}^{3}$ beaker, and zinc-chloride solution was poured on top of it. 164 While the carbonized wood floated to the surface of the solution, bones, teeth, as well as 165 molluscan shells, accumulated on the bottom of the beaker. The floating waste was removed 166 with a small kitchen sieve, after which the solution was decanted, and the residue was washed 167 and decanted repeatedly with water to remove the weakly acidic solution left in the pores of 168 the vertebrate remains. Consequently, the black or dark brown vertebrate specimens (small 169 bone fragments and teeth) could be more easily separated from the white molluscan shells 170 under a light microscope. However, this method has several drawbacks and is far from ideal. 171 First, although fortunately not as expensive as other alternatives such as polytungstate, the 172 usage of zinc-chloride is quite costly when used for large-scale separation: the total amount of $173 \mathrm{ZnCl}_{2}$ used for separation of the residue of the $60 \mathrm{~kg}$ sediment was about $20 \mathrm{~kg}$. Second, its 174 solution is acidic, which means that it can cause damage to vertebrate remains if not used 175 rapidly enough and not washed out properly. Third, it reacts with the calcareous components 176 of the residue, so that it cannot be re-used (also hindered by black colouration caused by tiny 
177 carbonized wood particles). Fourth, careful safety measures have to be taken to avoid skin

contact and inhalation. In short, the use of $\mathrm{ZnCl}_{2}$ as a heavy liquid for the separation of

microvertebrate remains in screenwashing residues is an operable method, but a more

practical substitute still needs to be found for large-scale $(>1.000 \mathrm{~kg})$ screenwashing and separation.

\section{Description and comparisons}

Osteichthyes Huxley, 1880

Actinopterygii Klein, 1885

Pycnodontiformes Lehman, 1966

Pycnodontiformes indet.

Fig. 5A, C-E.

Material. Fifteen isolated teeth (MTM V.2000.32; MTM VER 2015.18; MTM VER 2015.20; MTM VER 2015.22).

Description. The two largest teeth (overall length 4.5 and $3.9 \mathrm{~mm}$, respectively) are oval in shape, have a worn and smooth occlusal surface and are identical to those described from Iharkút (Gulyás, 2009; Ösi et al., 2012; see Fig. 5C). Four teeth are oval to slightly triangular, unabraded, or only slightly worn, showing complex occlusal crown morphology. They have a central groove that is shallow and wide on some of the teeth or deeper and elongate on others, and its margins are ornamented occlusally by shallow bumps and short radial grooves (Fig. $5 \mathrm{D}-\mathrm{E})$.

Five hooked and labio-lingually strongly flattened teeth (MTM VER 2015.20; $1 \mathrm{~mm}<$ overall length $<2 \mathrm{~mm}$ ) may represent pharyngeal teeth of pycnodontiforms. These have a slightly transparent crown with a pointed apex (Fig. 5A). 
Holostei Müller, 1845

Lepisosteiformes Hay, 1930

Lepisosteidae Cuvier, 1825

\section{Lepisosteidae indet.}

207 Figs. 4A-B, 5B.

208 Material. Ten isolated teeth (MTM VER 2015.19; MTM VER 2015.23) and a single vertebra 209 (MFGI V.18761).

210 Description. As typically seen in lepisosteiform teeth, they are pointed, conical in shape and 211 have lanceolate, smooth crowns with circular cross sections. Closer to the base, they bear fine 212 longitudinal grooves (Fig. 5B). Their size ranges from one to three millimetres. These teeth 213 are virtually identical to lepisoteid teeth described from the Csehbánya Formation (Ösi et al., 214 2012). They markedly differ from the pointed, non-lanceolate fang teeth of the main tooth 215 row of Lepisosteus and more similar to those of the lanceolate teeth seen Atractosteus 216 (Grande, 2010). The teeth from the Ajka Coal Formation, however, have an apically more 217 rounded crown.

218 The vertebra (Fig. 4A-B) is laterally wider than high (maximum width $7 \mathrm{~mm}$; greatest length $2194.5 \mathrm{~mm}$ ), slightly opisthocoel and the centrum has oval articulation surfaces. Short transverse 220 processes are present laterally.

222 Sauropsida Goodrich, 1916

223 Testudines Linnaeus, 1758

224 Eupleurodira Gaffney and Meylan, 1988 (sensu Gaffney, Tong and Meylan, 2006)

225 Pelomedusoides Cope, 1868

226 Bothremydidae Baur, 1891 


\section{Bothremydidae indet.}

228 Fig. 4C-E. 
251 Description. This specimen was collected in 2000 from the Ajka Coal Formation on spoil

heaps of the collieries (Makádi et al., 2012), and it actually represents the first specimen of

Pannoniasaurus ever found, although not recognised as such until subsequent finds at Iharkút

were made. This vertebra was tentatively referred to as Pannoniasaurus in the original description of the genus, on the basis of general morphological similarity to hundreds of Pannoniasaurus vertebrae found at Iharkút (Makádi et al., 2012).

The dorsal vertebra measures $36 \mathrm{~mm}$ in length, suggesting a total body length of around 3.5 metres for this individual, as compared to relative sizes of mosasaurs (Russell, 1967) and modern varanoids (LM, pers. obs. on a juvenile Varanus niloticus). It is heavily distorted by lateral compression and dorsal structures are incomplete. The neural canal is visible only at the posterior end and the left postzygapophysis is more or less intact with the left zygantrum, while the left prezygapophysis and neural spine are broken, having only their bases preserved. The structures on the right side are either crushed or missing, and have an elongated 3-cm-long bone fragment pressed in between them, which may correspond to a rib fragment. Despite its condition, the vertebra is similar in its observable morphological characteristics to those described for Pannoniasaurus (Makádi et al., 2012) and, albeit to a lesser extent, to those of Tethysaurus (Bardet et al., 2003). These similarities are as follows: the centrum is $\mathrm{V}$-shaped in ventral view, the condyle and cotyle are oval and oblique, the vertebral condyle was most probably flared (= precondylar constriction) as indicated by the worn edge of the condylar flange (the spongeous bony tissue is visible), and zygosphenes/zygantra were probably large and functional.

Although the specimen is compressed, it clearly has not suffered long transport, as 273 suggested by limited signs abrasion; as such, it is indicative of the presence of the genus also 274 in the Ajka area. The presence of Pannoniasaurus in the Ajka Coal Formation demonstrates 
that these freshwater mosasaurs were abundant not only in the floodplain area, but also in the lacustrine environment and most probably in the coastal swamps as well.

Crocodylomorpha Walker, 1970

Crocodyliformes Hay, 1930

Mesoeucrocodylia Whetstone and Whybrow, 1983

Mesoeucrocodylia indet.

\section{cf. Theriosuchus sp.}

Fig. 5I-K..

Material. Seven isolated teeth (MTM VER 2000.32; MTM VER 2015.25).

Description. Crocodyliform teeth are the commonest elements in the screenwashed material of the Ajka Coal Formation. Some of them are labiolingually flattened and pointed with slightly constricted crown and pseudoziphodont carinae (Fig. 5I-K). In some specimens the pseudoziphodont carina is barely recognised due to the poor preservation. The labiolingual surfaces of the crown are ornamented with fine longitudinal wrinkles that curve slightly mesially or distally to terminate at the carinae. The carina is not only a narrow, sharp keel, but a mesiodistally wider, flattened margin of the crown. The crowns of two additional teeth (MTM VER 2015.25) are strongly eroded, so neither the carinae nor the apical region can be observed. Only the basal half of the crown is preserved in these specimens, bearing longitudinal enamel wrinkles and a slightly constricted base.

The features seen in these teeth are most closely similar to those of the mesoeucrocodylian genus Theriosuchus from Upper Jurassic-Maastrichtian deposits (Martin et al., 2010, 2014, references therein), including the Santonian Csehbánya Formation (Ösi et al., 2012), and thus allow a tentative assignment as cf. Theriosuchus sp. 
Eusuchia Huxley, 1875

Hylaeochampsidae Andrews, 1913

Iharkutosuchus makadii Ösi, Clark and Weishampel, 2007

Fig. 5L-N.

Material. Two isolated teeth (MTM VER 2015.24).

Description. One of the specimens (Fig. 5L-M) referred to Iharkutosuchus is an anteriorly positioned, spatulate tooth identical to those described from Iharkút (Ösi, 2008). It has rounded, strongly constricted crown without cingulum or secondary rows of lingual cusps.

The crown surface is not completely smooth, but has a fine rugose texture. Labially the crown is spatulate with a slightly worn apical region. The spatulate part is divided by fine grooves into three parts both labially and lingually. There is a massive central portion bordered mesiodistally by flatter regions. The mesiodistal margins do not bear carinae.

The other tooth (Fig. 5N) has a slightly mesiodistally elongate, rectangular crown.

313 Based on its shape, it could have been a multicusped tooth, but its occlusal surface is strongly 314 eroded making the enamel-dentine junction well exposed. Though the outer outline of the 315 main row of cusps can be observed, the extent of wear makes the number of cusps or rows of 316 cusps parallel to the main row of cusps uncertain. The margin of the crown along the 317 secondary cusps is damaged making it slightly concave. The main row is composed of a large 318 central cusp, and a pair of smaller cusps mesially and distally. Compared to the teeth of 319 Iharkutosuchus from Iharkút, this specimen is from the median portion (11th-14th) of the 320 tooth row (Ösi, 2008).

322 Eusuchia indet.

323 cf. Allodaposuchus sp.

324 Fig. $5 \mathrm{~F}-\mathrm{H}$. 
Material. Ten isolated teeth (MTM VER 2015.21; MTM V.2000.22; MTM VER 2015.26).

Description. Some of the teeth are tall, pointed and labiolingually slightly flattened. Their

surface is ornamented by fine longitudinal enamel wrinkles, but in contrast to teeth of

Theriosuchus, the wrinkles do not terminate on the carinae (Fig. 5F-H). The carinae are sharp

and smooth, the crown being slightly constricted. A few other teeth are bulbous representing a more posterior tooth position (Fig. 5F). Most of the teeth have slightly worn apical regions (Fig. 5F). The morphology of these teeth occurs frequently among various eusuchian forms such as the Late Cretaceous basal eusuchian Allodaposuchus which is known from several European localities (Puértolas-Pascual et al., 2013, references therein), including the Santonian-aged locality of Iharkút (Rabi and Delfino, 2012; Ösi et al., 2012). Here we tentatively refer these teeth to cf. Allodaposuchus sp.

337 Ornithischia Seeley, 1888

338 Ankylosauria Osborn, 1923

339 Nodosauridae Marsh, 1890

340 Nodosauridae indet.

341 Figs. 4H-I, $5 \mathrm{O}$.

342 Material. A single tooth (MTM VER 2015.28) and an osteoderm (MFGI V.18762).

343 Description. A single tooth (Fig. 50) and a fragmentary osteoderm can be referred to 344 ankylosaurian dinosaurs. The tooth preserves the central portion of the crown and is strongly 345 worn. Neither the cuspidate carinae nor any of the cingula are preserved. In basal view the circular pulp cavity is visible. The labiolingually flattened, low and triangular crown is of proportions typical of ankylosaurian teeth.

The osteoderm (Fig. 4H-I) preserves approximately the central one quarter of the 349 complete element. Its greatest preserved dimensions are $33 \mathrm{~mm}$ anteroposteriorly and $45 \mathrm{~mm}$ 
lateromedially (the complete osteoderm could have been approximately $70-80 \mathrm{~mm}$ in length).

Of the original lateromedial margins it preserves a 21-mm-long part on one side and a 22mm-long part on the other. These margins are irregular and markedly crenulate as seen in ankylosaurian osteoderms. Most of the dorsal keel of the osteoderm was damaged during collecting, but it is clear that the keel is asymmetrically positioned being much closer to one of the margins of the element, a feature typically seen in marginal, oval-shaped ankylosaurian osteoderms. Based on this feature, the dorsal surface of the bone is slightly inclined on one side, yet steeply inclined on the other side of the keel. The inner structure of the bone is spongious as usual in ankylosaurian osteoderms.

Based on the features outlined above, the specimen can be clearly referred to ankylosaurs and it shows an identical morphology to the oval-shaped, medium-sized, lowkeeled osteoderms of Hungarosaurus tormai which is known from the stratigraphically equivalent alluvial Csehbánya Formation (Ösi, 2005; Ösi and Makádi, 2009). The lack of diagnostic features, however, prevents a more precise taxonomical assignment, especially given that a second nodosaurid taxon, Struthiosaurus, has also been recorded from Iharkút (Ösi and Prondvai, 2013).

Saurischia Seeley, 1888

Theropoda Marsh, 1881

\section{Theropoda indet.}

370 Fig. 5P-Q.

Material. A single tooth (MTM VER 2015.27).

372 Description. A single, small (apicobasal height $1.3 \mathrm{~mm}$, crown base length $0.9 \mathrm{~mm}$, crown 373 base width $0.4 \mathrm{~mm}$ ) pointed tooth (Fig. 5P-Q) can be referred to theropod dinosaurs. The 374 crown base is not constricted and it has a mesiodistally elongated, oval to flattened cross 
section with a low (0.44) crown base/crown height ratio. The crown curves distally under a crown angle of $57^{\circ}$. Bands of growth or enamel wrinkles are absent. Basally the labial and lingual sufaces of the crown are slightly concave. Neither of the carinae is serrated (Fig. 5Q).

Whereas the mesial carina is present in the sagittal plane of the crown, the distal carina extends slightly obliquely basally. Although unpublished, an almost identical isolated tooth has been found at Iharkút.

Teeth lacking serrations appear in several clades of theropods including unenlagiine dromaeosaurs (Buitreraptor Makovicky et al., 2005), ornithomimosaurs (Pelecanimimus Pérez-Moreno et al., 1994) and enantiornithine birds (Chiappe and Walker, 2002). In addition, the tooth-based taxa Paronychodon and Euronychodon are also characterised by the lack of serrated carinae. The smooth-edged theropod tooth from Ajka differs from those of enantiornithines and Pelecanimimus in the lack of a constricted crown base (Chiappe and Walker, 2002). Buitreraptor has roughly similar tooth crowns, but these are more distally curved (Makovicky et al., 2005) than the Ajka specimen. Paronychodon teeth are characterised by longitudinal grooves on at least one side of the crown (Zinke and Rauhut, 1994), and longitudinal ridges are present on the high, recurved teeth of Euronychodon described from the Upper Cretaceous of Portugal (Antunes and Russell, 1991). These features are not present on the tooth from Ajka. Although hesperornithid teeth also lack serrated carinae and have a generally similar outline of the crown in labiolingual view, they do show nearly planar lingual and strongly convex labial sides (Martin and Stewart, 1977; Martin et al., 1980) not present in the present specimen. Teeth of Ichthyornis are triangular and convex labiolingually (Martin and Stewart, 1977), but not as curved distally as the tooth from Ajka. 397 Some bird teeth with no serrations from the Upper Cretaceous of Alberta are similar in size 398 and cross section (Sankey et al., 2002, fig. 5/39-42), but they are proportionally taller and not 399 as curved distally as the Ajka tooth is. 
In conclusion, the theropod tooth with smooth carinae from Ajka has a crown

morphology similar to those of some dromaeosaurid and enantiornithine theropods. Post-

cranial remains of enantiornithines and dromaeosaurid-like Paravians are both present in

Iharkút, suggesting that this tooth might belong to one of these groups. The question whether it is from a bird (e.g., the buzzard-sized Bauxitornis) or from a dromaeosaurid, or perhaps an ornithomimid theropod, still remains open until more complete cranial material has been unearthed.

\section{Sauropsida indet.}

Fig. 4J-K.

Material. A single bone fragment (MFGI V.18765).

Description. A complex fragmentary bone (Fig. 4J-K) was recovered from the core of borehole Gy-12 (at a depth of $473 \mathrm{~m}$ ). The specimen is rather flat with one (probably outer) side being slightly ornamented by some shallow pits and grooves. The other (probably inner) side is concave with a smoother surface, and at least three nutritive foramina can be observed on its left side (Fig. 4H). This surface appears to be divided by two thin bone septa, the right one being at the cut end of the specimen. Due to core drilling the specimen was cut at two ends showing a relatively uniform, spongious inner texture.

\section{Discussion}

\subsection{Comparison of the vertebrate faunas of the Ajka Coal and Csehbanya Formations}

Vertebrate remains from the Ajka Coal Formation are extremely scanty compared to the diverse and rich assemblages collected from the Csehbánya Formation, but most of the specimens can still be referred to lower taxonomic levels. Although the two formations 
represent two different environments (see 5.2. chapter below), the composition of the Ajka vertebrate fauna greatly overlaps with that of Iharkút. Pycnodontiform and lepisosteiform fishes, bothremydid turtles, crocodilians including cf. Theriosuchus, Iharkutosuchus and cf. Allodaposuchus, the freshwater mosasaur Pannoniasaurus and ankylosaurian and theropod dinosaurs identified from the Ajka Coal Formation have all been recorded from the Csehbánya Formation as well. Remains of these taxa frequently occur in the Iharkút assemblage. It should be noted, however, that $I$. makadii and $P$. inexpectatus are the only taxa recognised at species level in both formations, and otherwise the taxonomic overlap is currently only confirmed at higher taxonomic levels. The only taxon represented by a single tooth from both formations is a theropod dinosaur (Fig. 5P-Q). In 2014, a similarly small, distally curved tooth with no serrations was discovered from the Csehbánya Formation by sorting the screenwashed residue of several tonnes of sediment, indicating that this theropod was quite uncommon in the Iharkút setting. Although there is no evidence yet of enantiornithine birds from the Ajka Coal Formation, the Ajka theropod tooth might belong to this group, which is also poorly known from skeletal elements (i.e, a few limb bones) from the Csehbánya Formation (Dyke and Ösi, 2010).

Based on the few, mainly microvertebrate, remains described here, the Ajka fauna is dominated by aquatic or semi-aquatic forms, truly terrestrial elements being solely ankylosaurian and theropod dinosaurs. This composition probably correlates with the lesser degree of sediment transport into the swampy environment of the Ajka Basin during the deposition of coal-bearing beds as compared to that of the floodplain environment of a very low-gradient river in the Iharkút area (Botfalvai et al., 2015). The low amount of allochthonous sediment particles (i.e., sand, silt) in the fossiliferous coal-bearing beds is suggestive of autochthonous deposition of the specimens found by screenwashing. The taxa in common between the Ajka and Iharkút faunas suggest that these forms probably inhabited at 
least two different, yet contemporaneous freshwater environments. In the case of

Iharkutosuchus makadii, freshwater molluscs present in both the Ajka Coal and Csehbánya formations could constitute to a potential food resource judged from its inferred omnivorous diet including hard-shelled prey on the basis of tooth wear analysis (Ösi and Weishampel, 2009).

Of the ankylosaurian remains from the Ajka Coal Formation the highly eroded preservation of the tooth may reflect an extended period of transport. The partially intact margins of the osteoderm (MFGI V.18762), however, are suggestive of an autochthonous origin. A taphonomic analysis of the very abundant ankylosaur material from Iharkút (Botfalvai et al., 2015) has strengthened the theory that ankylosaurs preferred wetland habitats such as fluvial systems and coastal regions (Horner, 1979; Lee, 1996; McCrea et al., 2001) and the ankylosaurs from the Ajka Coal Formation are therefore consistent with this pattern. The abundance of teeth referred to the crocodilian cf. Allodaposuchus in the Ajka Coal Formation may suggest that these small- to medium-sized freshwater predators were common elements in both the swampy environment of Ajka and the floodplains of Iharkút.

\subsection{Palaeoenvironment}

The present distribution of the Ajka Coal Formation indicates that it was laid down at least in three different subbasins near Ajka, Magyarpolány-Devecser and Gyepükaján (Császár and Góczán, 1988). The Ajka and Magyarpolány-Devecser subbasins went through similar sedimentary events, with sequences starting with freshwater, shallow-swamp strata deposited during the palynological zones A or B. In the macrospore flora forms related to 472 Isoetaceae are common. By the time of zone $\mathrm{C}$, the environment had turned into a lacustrine, 473 nutrient-rich marsh in the Ajka Subbasin, while at Magyarpolány the fluvial influence became 474 more dominant, and the area was filled with fluvial sediments (Siegl-Farkas, 1988). Frequent 
remains of seeds and fruits from the Magyarpolány Subbasin suggest an arboraceous

environment (Rákosi and Barbacka, 2000).

During the time of palynological zones A and B the third subbasin, Gyepükaján, was permanently covered by freshwater and the environment was lacustrine based on algal flora (Rákosi and Barbacka, 2000). It has been suggested that a sequence of Dachstein Limestone partly closed the Gyepükaján Subbasin towards the east-north-east of the other subbasins (Császár and Góczán, 1988). By the time of zone C a freshwater marsh environment became dominant in this area as well.

The environment changed during the time interval of zone $\mathrm{D}$, when marine influence became more characteristic. The coal formation became lagoonal paralic in nature, the flora and invertebrate fauna being unified. Based on ostracod (Monostori, 1988) and molluscan studies (Czabalay, 1988) the water became brachyhaline to mesohaline.

The palynological data suggest Normapolles-related forests with fern-dominated underwood in a tropical or subtropical climate during the deposition of the Ajka Coal and Csehbánya Formations (Siegl-Farkas and Wagreich, 1996; Bodor and Baranyi, 2012). Seasonality of precipitation can be presumed, as based on the tree rings in fossil wood related to Araucaria (L. Rákosi, pers. comm., 08. 2003).

Coal deposition in the Ajka region was characteristic during the time interval of the palynozones B-D. Plant mesofossils were very common in the area of the Jókai Mine, being suggestive of their autochthonous nature. For example, Padragkutia haasi is one of the most abundant species representing a wetland forest (Rákosi, 1991). Podocarpoxylon ajkaense has also been described from this subbasin and might have been the dominant coal-forming conifer in the area (Greguss, 1949).

Vertebrate remains from the Ajka Subbasin (lepisosteiform and pycnodontiform 499 fishes, bothremydid turtles, Pannoniasaurus, Theriosuchus, Iharkutosuchus, Allodaposuchus, 
ankylosaurian and theropod dinosaurs) were found in chunks of the coal-bearing strata as dumped on the spoil heaps of the Jókai Mine, which means that their exact stratigraphic provenance cannot be determined. Vertebrate remains (lepisosteiform fishes, bothremydid turtles, ankylosaurian dinosaurs) brought up by drilling are from boreholes Gy-12 and Kf-2, representing the Gyepükaján Subbasin, and their exact stratigraphic position could be determined. A single unidentified bone fragment (MFGI V.18765) originates from a depth of $473 \mathrm{~m}$ in borehole Gy-12, from which level also spores of Cyathidites austrialis, Leiotriletes sp. and Lobasporites lobatus have been described (Rákosi and Barbacka, 2000). Thus, this level corresponds to the boundary of palynozones $\mathrm{C}$ and $\mathrm{D}$, as based on correlations with palynoflora of wells Gy-9 and Kf-6. Marine influence cannot be ruled out in the bone-bearing section of borehole Gy-12.

In the case of borehole Kf-2, the vertebrate remains (bothremydid turtles, ankylosaurian dinosaurs) were recovered from a depth of 803 and 804 metres. Here, Horstisporites harrisii and Erlanisporites spinosus macrospores were found together with the planktonic Schizosporites reticulatus. In addition, Munieria-related green algae and Azollopsis pusilla were found (Rákosi and Barbacka, 2000). These imply a lacustrine, freshwater environment and the Operculispermum seeds suggest that the wetland forest was relatively close to the depositional environment. Costatheca and Spermatites are also common at this level, but their precise taxonomic affinity remains uncertain.

\section{Conclusions}

Although the fossiliferous, coal-bearing beds of the Upper Cretaceous Ajka Coal 522 Formation have been known for 150 years, the first informative vertebrate remains were 523 discovered only during the last three decades. These remains include macroscopic specimens 524 from boreholes Kf-2 and Gy-12, as well as macro- and microscopic remains collected by 
manual breakup and/or screenwashing of chunks of matrix dumped on the spoil heaps of the Jókai Mine. They represent lepisosteiform and pycnodontiform fishes, bothremydid turtles, mosasaurs (Pannoniasaurus inexpectatus), crocodilians referred to cf. Allodaposuchus, cf. Theriosuchus and Iharkutosuchus makadii, and ankylosaurian and theropod dinosaurs. Microvertebrate remains indicate that, similar to the Iharkút fauna, semi-aquatic forms of crocodilians were the predominant inhabitants of the swampy lacustrine habitats of the Ajka Subbasin. The fauna of the Ajka Coal Formation strongly overlaps with that of the contemporaneous Csehbánya Formation, suggesting the occurrence of these taxa in the swampy environments as well as along the floodplains of a very low-gradient river.

\section{Acknowledgements}

We thank the two anonymous reviewers for their constructive comments that greatly improved the manuscript. We thank Ágnes Siegl-Farkas, Zoltán Partényi and László Rákosi for useful consultation, and Zsófia Hajdu, Gábor Czirják, Péter Gulyás and Ferenc Szőke for assistance during fieldwork. We are especially grateful to Réka Kalmár for her help in screenwashing of the samples, and Márton Szabó for picking specimens from the residue. Field and laboratory work was supported by the MTA-ELTE Lendület Dinosaur Research Group (grant no. 95102), the Hungarian Scientific Research Fund (OTKA T-38045, PD 73021, NF 84193), the Geological and Geophysical Institute of Hungary (National project: 2014/11.1), a Bolyai Fellowship (to AÖ), the Hungarian Natural History Museum, the Eötvös Loránd University, and the Jurassic Foundation and Hantken Foundation. This research received support from the SYNTHESYS Project (http://www.synthesys.info/), which is 547 financed by European Community Research Infrastructure Action under the FP7 "Capacities" 548 Program (FR-TAF 4290, GB-TAF-1882, NL-TAF 3200, BE-TAF-5292; grants awarded to 549 MR and SE-TAF 2066 grant awarded to ERB). 
Andrews, C.W., 1913. On the skull and part of the skeleton of a crocodile from the Middle Purbeck of Swanage, with the description of a new species (Pholidosaurus laevis), and a note on the skull of Hylaeochampsa. Annals and Magazine of Natural History 8, 485-494.

Antunes, M.T., Sigogneau-Russell, D., 1991. Nouvelles données sur les dinosaures du Crétacé supérieur du Portugal-Comptes Rendus de l'Académie des Sciences Paris (2)313, 113-119.

Bandel, K., Riedel, F., 1994. The Late Cretaceous gastropod fauna from Ajka (Bakony Mountains, Hungary): a revision. Annalen des Naturhistorischen Museums Wien 96A, 1-65.

Bardet, N., Suberbiola, X.-P., Jalil, N.-E., 2003. A new mosasauroid (Squamata) from the Late Cretaceous (Turonian) of Morocco. Comptes Rendus Paleovol 2, 607-616.

Baur, G., 1891. Notes on some little known American fossil tortoises. Proceedings of the Academy of Natural Sciences of Philadelphia 43, 411-430.

Bodor, E., Baranyi, V., 2012. Palynomorphs of the Normapolles group and related plant mesofossils from the Iharkút vertebrate site, Bakony Mountains (Hungary). Central European Geology 55, 259-292.

Bodrogi, I., Fogarasi, A., Yazikova, E.A., Sztanó, O., Báldi-Beke, M., 1998. Upper Cretaceous of the Bakony Mts. (Hungary): sedimentology, biostratigraphy, correlation. Zentralblatt für Geologie und Paläontologie (I)1996, 1179-1194.

Botfalvai, G., Ösi, A., Mindszenty, A., 2015. Taphonomic and paleoecologic investigations of the Late Cretaceous (Santonian) Iharkút vertebrate assemblage (Bakony Mts, northwestern Hungary).

Palaeogeography, Palaeoclimatology, Palaeoecology 417, 379-405.

Camp, C., 1923. Classification of the lizards. Bulletin of the American Museum of Natural History 48, $289-481$.

Chiappe, L.M., Walker, C.A., 2002. Skeletal morphology and systematics of the Cretaceous Euenantiornithes (Ornithothoraces: Enantiornithes), in: Chiappe, L.M., Witmer L. M. (Eds.), 
Mesozoic birds: above the heads of the dinosaurs. University of California Press, Berkeley, pp. 240-267.

Cope, E.D., 1868. On the origin of genera. Proceedings of the Academy of Natural Sciences of Philadelphia 20, 242-300.

Cuvier, G. 1825. Recherches sur les ossemens fossiles, oú l'on rétablit les caractéres de plusieurs animaux dont les révolutions du globe ont détruit les espéces. 3rd ed., vol. 3., G. Dofour et E. d'Ocagne, Paris.

Császár, G.H., Góczán, F., 1988. A Bakony felső-kréta kőszénkutatás és kőszén lápvizsgálat [Upper Cretaceous coal prospecting and peat bog studies in the Bakony Mts]. Magyar Állami Földtani Intézet Évi Jelentése 1986-ról, 155-178.

Czabalay, L., 1988. Az Ajkai Kőszén Formáció őskörnyezeti viszonyai a kagyló és csiga fauna alapján [Paleoecological study of the Ajka Coal Formation upon bivalves and gastropods]. Magyar Állami Földtani Intézet Évi Jelentése 1986-ról, 211-227.

Dyke, G., Ősi, A., 2010. Late Cretaceous birds from Hungary: implications for avian biogeography at the close of the Mesozoic. Geological Journal 45, 434-444.

Gaffney, E.S., Meylan, P.A., 1988. A phylogeny of turtles, 157-219. In: Benton, M.J. (Ed.), The phylogeny and classification of the tetrapods, Vol. 1, Amhibians, reptiles, birds. Systematics Association Special Volume 35A.

Gaffney, E.S., Tong, H., Meylan, P.A., 2006. Evolution of the side-necked turtles: the families Bothremydidae, Euraxemydidae, and Araripemydidae. Bulletin of the American Museum of Natural History 300, 1-698.

Goodrich, E.S., 1916. On the classification of the Reptilia. Proceedings of the Royal Society London $89,261-276$.

Grande, L., 2010. An empirical and synthetic pattern study of gars (Lepisosteiformes) and closely related species, based mostly on skeletal anatomy. The resurrection of Holostei. American Society of Ichthyology and. Herpetology, Special Publications 6, 1-871. 
Greguss, P., 1949. Az ajkai felső-kréta korú barnaköszén fusitzárványának meghatározasa

(Podocarpoxylon ajkaense $\mathrm{n}$. sp.) [Determination of the fusit inclusion from the Upper Cretaceous brown coal of Ajka]. Földtani Közlöny 79, 9-12.

Gulyás, P., 2009. The fish fauna of the Late Cretaceous santonian continental vertebrate locality of Iharkút (Bakony Mountains, Hungary). Journal of Vertebrate Paleontology 29 (Suppl. to no. 3), 109A.

Haas, J., 1983. Senonian in the Transdanubian Central Range. Acta Geologica Hungarica 26, 21-40.

Haas, J., Jocha Edelényi, E., 1979. A dunántúli-középhegységi felsőkréta üledékciklus ősföldrajzi elemzése [Paleogeography of the Upper Cretaceous sedimentary cycle of the Transdanubian Central Range]. A Magyar Állami Földtani Intézet évi jelentése az 1977. évröl, 217-223.

Haas, J., Jocha-Edelényi, E., Császár, G., 1992. Upper Cretaceous coal deposits in Hungary, in: McCabe, P., Parris, J.T. (Eds.), Controls on the distribution and quality of Cretaceous coals. Geological Society of America, Special Paper 267, 245-262.

Hay, O.P., 1930. Second bibliography and catalogue of the fossil Vertebrata of North America. Carnegie Institute of Washington Publication 3902, 1-1074.

Horner, J.R., 1979. Upper Cretaceous dinosaurs from the Bearpaw Shale (marine) of south-central Montana with a checklist of Upper Cretaceous dinosaur remains from marine sediments in North America. Journal of Paleontology 53, 566-577.

Huxley, T.H., 1875. On Stagonolepis Robertsoni, and on the evolution of the Crocodilia. Quarterly Journal of the Geological Society London 3, 423-438.

Huxley, T.H., 1880. On the application of the laws of evolution to the arrangement of the Vertebrata, and more particularly of the Mammalia. Proceedings of the Zoological Society London 1880, $649-662$.

Jocha-Edelényi, E., 1988. History of evolution of the Upper Cretaceous Basin in the Bakony Mts at the time of the terrestrial Csehbánya Formation. Acta Geologica Hungarica 31, 19-31.

Klein, E.F., 1885. Beiträge zur Bildung des Schädels der Knochenfische, 2. Jahreshefte Vereins Vaterländischer Naturkunde in Württemberg 42, 205-300. 
630 Kozma, K., 1991. Az ajkai szénbányászat története [History of coal mining in Ajka]. Veszprémi Szénbányák kiadványa, Veszprém, 531 pp.

Lee, Y.-N., 1996. A new nodosaurid ankylosaur (Dinosauria: Ornithischia) from the Paw Paw Formation (Late Albian) of Texas. Journal of Vertebrate Paleontology 16, 232-245.

Lehman, J.P., 1966. Actinopterygii, in: Piveteau, J. (Ed.), Traité de Paléontologie, Tome IV. Masson et Cie, Paris, pp. 1-242.

Linnaeus, C., 1758. Systema naturae per regna tria naturae, secundum classes, ordines, genera, species, cum characteribus, differentiis, synonymis, locis. Editio decima, reformata. Holmiae, Laurentius Salvius, $824 \mathrm{pp}$.

Makádi, L., Caldwell, M.W., Ösi, A., 2012. The first freshwater mosasauroid (Upper Cretaceous, Hungary) and a new clade of basal mosasauroids. PLoS ONE 7, e51781. doi:10.1371/journal.pone.0051781

Makovicky, P.J., Apesteguía, S., Agnolín, F.L., 2005. The earliest dromaeosaurid theropod from South America. Nature 437, 1007-1011.

Marsh, O.C., 1881. Principal characters of American Jurassic dinosaurs. Part V. The American Journal of Science and Arts (3)21, 417-423.

Marsh, O.C., 1890. Additional characters of the Ceratopsidae with notice of new Cretaceous dinosaurus. The American Journal of Science (3)39: 418-426.

Martin, J., Rabi, M., Csiki, Z., 2010. Survival of Theriosuchus (Mesoeucrocodylia: Atoposauridae) in a Late Cretaceous archipelago: a new species from the Maastrichtian of Romania. Naturwissenschaften 97, 845-854.

Martin, J.E., Rabi, M., Csiki-Sava, Z., Vasile, S., 2014. Cranial morphology of Theriosuchus sympiestodon (Mesoeucrocodylia, Atoposauridae) and the widespread occurrence of Theriosuchus in the Late Cretaceous of Europe. Journal of Paleontology 88, 444-456.

Martin, L.D., Stewart, J.D., 1977. Teeth in Ichthyornis (Class: Aves). Science 195, 1331-1332.

Martin, L.D., Stewart, J.D., Whetstone, K.N., 1980. The origin of birds: structure of the tarsus and teeth. Auk 97, 86-93. 
McCrea, R.T., Lockley, M.G., Meyer, C.A., 2001. Global distribution of purported ankylosaur track occurrence. In: Carpenter, K. (Ed.), The armored dinosaurs. Bloomington, Indiana University Press, pp. 413-454.

Monostori, M., 1988. Jelentés az ajkai felső-kréta kőszénterület Ostracoda faunáinak vizsgálatáról [Report on the ostracod fauna of the Upper Cretaceous Ajka Coal Subbasin]. Unpublished manuscript, $17 \mathrm{pp}$.

Müller, J., 1845. Über den Bau und die Grenzen der Ganoiden, und über das natürliche System der Fische. Archiv für Naturgeschichte 1(11), 91-141.

Oppel, M., 1811. Die Ordnungen, Familien und Gattungen der Reptilien als Prodom einer Naturgeschichte derselben. München, Joseph Lindauer Verlag, 86 pp.

Osborn, H.F., 1923. Two Lower Cretaceous dinosaurs from Mongolia. American Museum Novitates $95,1-10$.

Ösi, A., 2005. Hungarosaurus tormai, a new ankylosaur (Dinosauria) from the Upper Cretaceous of Hungary. Journal of Vertebrate Paleontology 25, 370-383.

Ösi, A., 2008. Cranial osteology of Iharkutosuchus makadii, a Late Cretaceous basal eusuchian crocodyliform from Hungary. Neues Jahrbuch für Geologie und Paläontologie Abhandlungen 248, 279-299.

Ösi, A., Makádi, L., 2009. New remains of Hungarosaurus tormai (Ankylosauria, Dinosauria) from the Upper Cretaceous of Hungary: skeletal reconstruction and body mass estimation. Paläontologische Zeitschrift 83, 227-245.

Ösi, A., Prondvai, E., 2013. Sympatry of two ankylosaurs (Hungarosaurus and cf. Struthiosaurus) in the Santonian of Hungary. Cretaceous Research 44, 58-63.

Ösi, A., Weishampel, D.B., 2009. Jaw mechanism and dental function in the Late Cretaceous basal eusuchian Iharkutosuchus. Journal of Morphology 270, 903-920.

Ösi A., Clark, J.M., Weishampel, D.B., 2007. First report on a new basal eusuchian crocodyliform with multicusped teeth from the Upper Cretaceous (Santonian) of Hungary. Neues Jahrbuch für Geologie und Paläontologie Abhandlungen 243, 169-177.

Ősi, A., Makádi, L., Rabi, M., Szentesi, Z., Botfalvai, G., Gulyás, P., 2012. The Late Cretaceous 
continental vertebrate fauna from Iharkút, western Hungary: a review, in: Godefroit, P. (Ed.), Bernissart dinosaurs and Early Cretaceous terrestrial ecosystems. Bloomington, Indiana University Press, pp. 533-568.

Ösi, A., Pozsgai, E., Botfalvai, G., Götz, A.E., Prondvai, E., Makádi, L., Hajdu, Zs., Csengődi, D., Czirják, G., Sebe, K., Szentesi, Z., 2014. The first report of Triassic vertebrate assemblages from the Villány Hills (southern Hungary). Central European Geology 56, 297-335.

Pérez-Moreno, B.P., Sanz, J.L., Buscalioni, A.D., Moratalla, J.J., Ortega, F., Rasskin-Gutman, D., 1994. A unique multitoothed ornithomimosaur from the Lower Cretaceous of Spain. Nature 370, $363-367$.

Puértolas-Pascual, E., Canudo, J.I., Moreno-Azanza, M., 2013. The eusuchian crocodylomorph Allodaposuchus subjuniperus sp. nov., a new species from the latest Cretaceous (upper Maastrichtian) of Spain. Historical Biology 26, 91-101.

Rabi, M, Delfino, M., 2012. A reassessment of the 'alligatoroid' eusuchian from the Late Cretaceous of Hungary and its taxonomic implications. In: Royo-Torres, R., Gascó, F., Alcalá, L. (Eds.), Fundamental, 10th Annual Meeting of the European Association of Vertebrate Palaeontologists; 2012, June 19-24, Teruel, Spain, Vol. 20. Teruel, Fundación Conjunto Paleontológico de TeruelDinópolis, pp. 203-206.

Rabi, M., Tong, H., Botfalvai, G., 2012. A new species of the side-necked turtle Foxemys (Pelomedusoides: Bothremydidae) from the Late Cretaceous of Hungary and the historical biogeography of the Bothremydini. Geological Magazine 149, 662-674.

Rákosi, L., 1991. Paleokarpological investigations of the Cretaceous and Tertiary in Hungary. Őslénytani Viták 36-37, 127-133.

Rákosi, L., Barbacka, M., 2000. Upper Cretaceous flora from Ajka (SW Hungary). I. Thallophyta. Studia Botanica Hungarica 30-31, 27-55.

Russell, D.A., 1967. Systematics and morphology of American mosasaurs. Bulletin of the Peabody Museum of Natural History 23, 1-240. 
711 Sankey, J.T., Brinkman, D.B., Günther, M., Currie, P.J., 2002. Small theropod and bird teeth from the

Late Cretaceous (Late Campanian) Judith River Group, Alberta. Journal of Paleontology 76, 751763.

Seeley, H.G., 1888. The classification of the Dinosauria. Report of the British Association of Advancement of Science 1887, 698-699.

Siegl-Farkas, Á., 1988. Az Ajkai Kőszén Formáció palynosztratigráfiája és fejlődéstörténete [Palynostratigraphy and evolution of the Ajka Coal Formation]. Magyar Állami Földtani Intézet Évi Jelentése 1986-ról, 179-209.

Siegl-Farkas, Á., Wagreich, M., 1996. Correlation of palyno- (spores, pollen, dinoflagellates) and calcareous nannofossil zones in the Late Cretaceous of the Northern Calcareous Alps (Austria) and the Transdanubian Central Range (Hungary). - Advances in Austrian-Hungarian Joint Geological Research, Budapest. 127-135.

Tausch, L., 1886. Über die Fauna der nicht marinen Ablagerungen der oberen Kreide des Csingerthales bei Ajka im Bakony (Veszprimer Comitat, Ungarn). Abhandlungen der kaiserlichen und königlichen Geologischen Reichsanstalt 12, 1-32.

Walker, A.D., 1970. A revision of the Jurassic reptile Hallopus victor (Marsh), with remarks on the classification of crocodiles. Philosophical Transactions of the Royal Society of London B257, $323-372$.

Whetstone, K.N., Whybrow, P.J., 1983. A “cursorial” crocodilian from the Triassic of Lesotho (Basutoland), southern Africa. Occasional Papers of the Museum of Natural History, University of Kansas 106, 1-37.

Zinke, J., Rauhut, O.W.M., 1994. Small theropods (Dinosauria, Saurischia) from the Upper Jurassic and Lower Cretaceous of the Iberian Peninsula. Berliner geowissenschaftliche Abhandlungen E13, $163-177$. 
CAPTIONS

Fig. 1. Localities yielding Late Cretaceous vertebrate fossils, distribution and geology of the Ajka Coal Formation; (A) location of the Ajka Coal area in western Hungary; (B)

distributional map of the Ajka Coal Formation (light grey) with position (green triangles) of boreholes Káptalanfa-2 (Kf-2) and Gyepükaján-12 (Gy-12) (after Császár and Góczán, 1988), the spoil heaps of the Jókai Mine in the Ajka Subbasin (green asterisk), and the locality of Iharkút (green circle). The red dashed line shows the position of the section in C; (C) simplified geological section of the Ajka Subbasin (after Kozma, 1991).

Fig. 2. Stratigraphy of well Káptalanfa-2 (after Haas et al., 1992); B-D are palynozones (after Siegl-Farkas, 1988). The ankylosaur skeleton marks the position of the ankylosaurian osteoderm (MFGI V.18762) and bothremydid turtle shell fragments (MFGI V.18763; MFGI V.18764) discovered in this core.

753 Fig. 3. Age of vertebrate remains calibrated with palynological zones (after Siegl-Farkas, 754 1988; Siegl-Farkas and Wagreich, 1996; Bodrogi et al., 1998).

inexpectatus (MTM V.2000.21), dorsal vertebra in right and left lateral views, respectively;

(H-I) Ankylosauria indet., osteoderm in core (MFGI V.18762) in dorsal view and line 
762 drawing of the same, respectively; (J-K) unidentified sauropsid bone (MFGI V.18765) in

1

inner and outer views, respectively.

Fig. 5. Microvertebrate remains from the Ajka Coal Formation discovered by manual breakup and screenwashing of matrix from spoil heaps of the Jókai Mine in the Ajka Subbasin; (A) Pycnodontiformes indet., pharyngeal tooth (MTM VER 2015.20); (B) Lepisosteidae indet., tooth crown (MTM VER 2015.19); (C) Pycnodontiformes indet., tooth (MTM VER 2015.18) in occlusal view; (D) Pycnodontiformes indet., tooth (MTM VER 2015.22) in occlusal view; (E) Pycnodontiformes indet., tooth (MTM VER 2015.18) in occlusal view; (F) cf. Allodaposuchus sp., posterior tooth (MTM VER 2015.21) in ?labial view; (G) cf. Allodaposuchus sp., tooth (MTM V.2000.22) in labial view; (H) cf. Allodaposuchus sp., tooth (MTM VER 2015.26) in lingual view; (I) cf. Theriosuchus sp., tooth (MTM V 2000.32) in lingual view; (J-K) cf. Theriosuchus sp., tooth (MTM VER 2015.25) in occlusal and lingual views, respectively; (L-M) Iharkutosuchus makadii, incisiviform tooth (MTM VER 2015.24) in lingual and ?mesial views, respectively; (N) Iharkutosuchus makadii, strongly worn multicusped tooth (MTM VER 2015.24) in occusal view; (O) Ankylosauria indet., strongly worn and broken tooth (MTM VER 2015.28) in ?lingual view; (P-Q) Theropoda indet., tooth (MTM VER 2015.27) in ?lingual and distal views, respectively. 


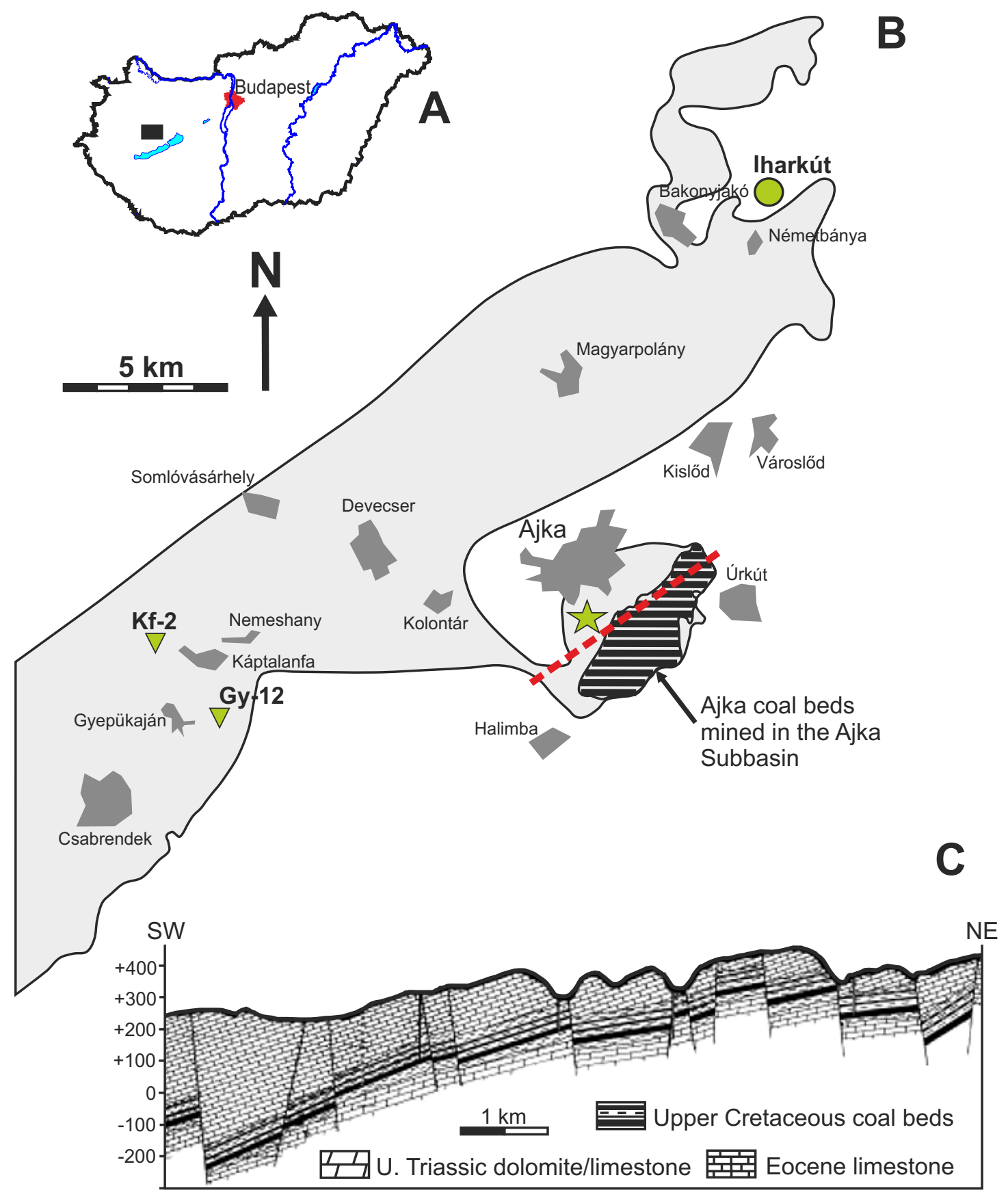




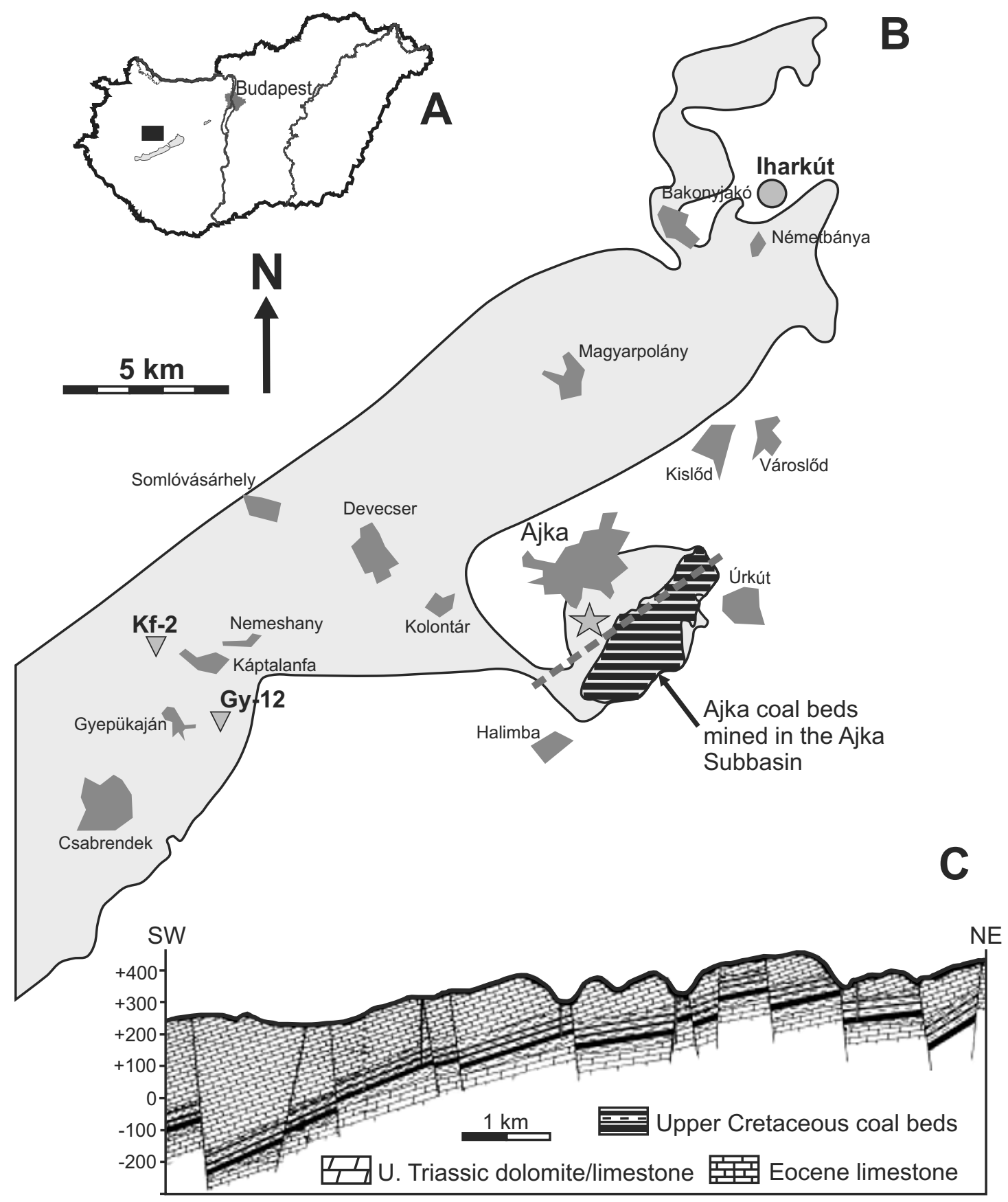


Figure 2 color

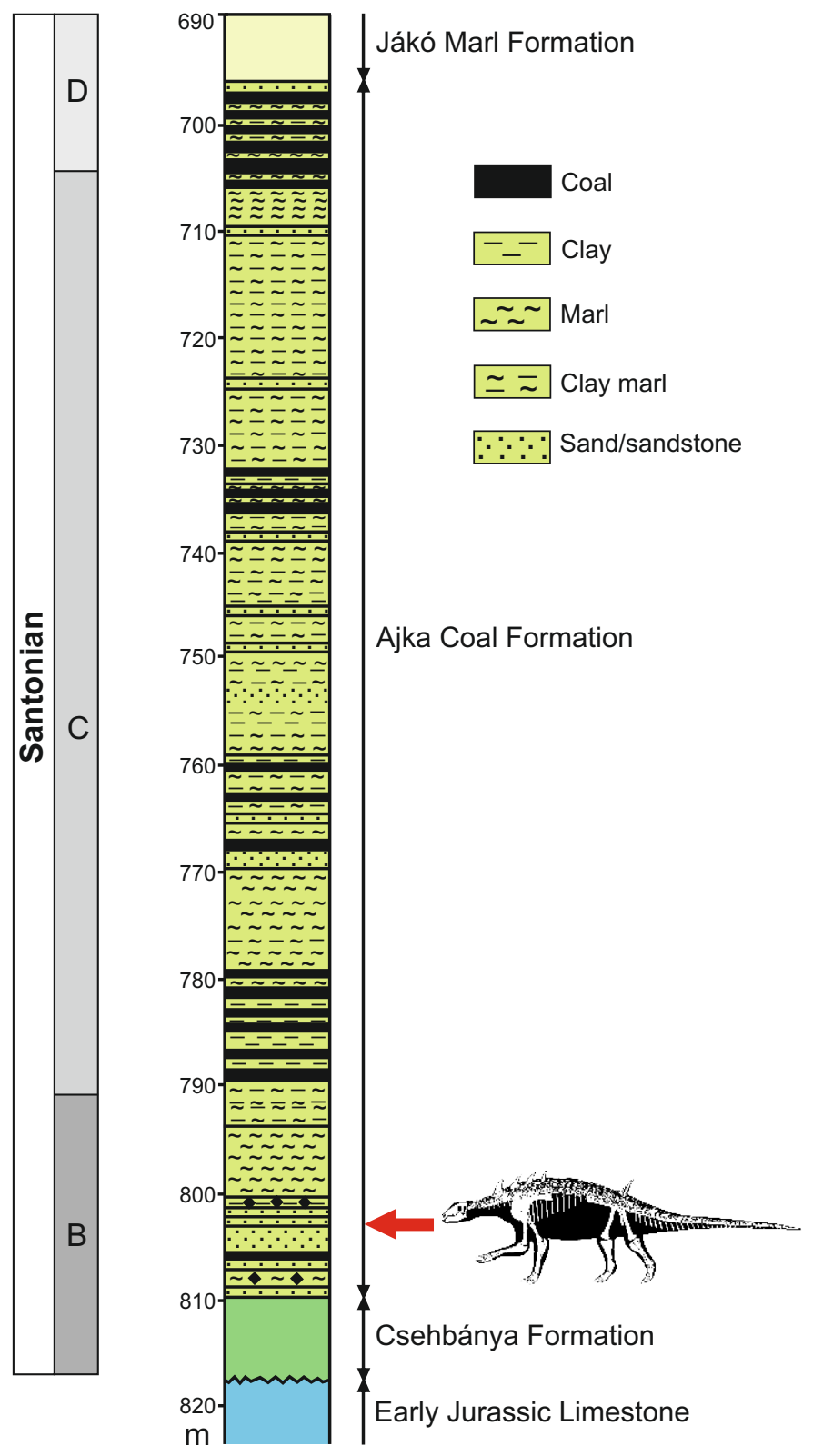




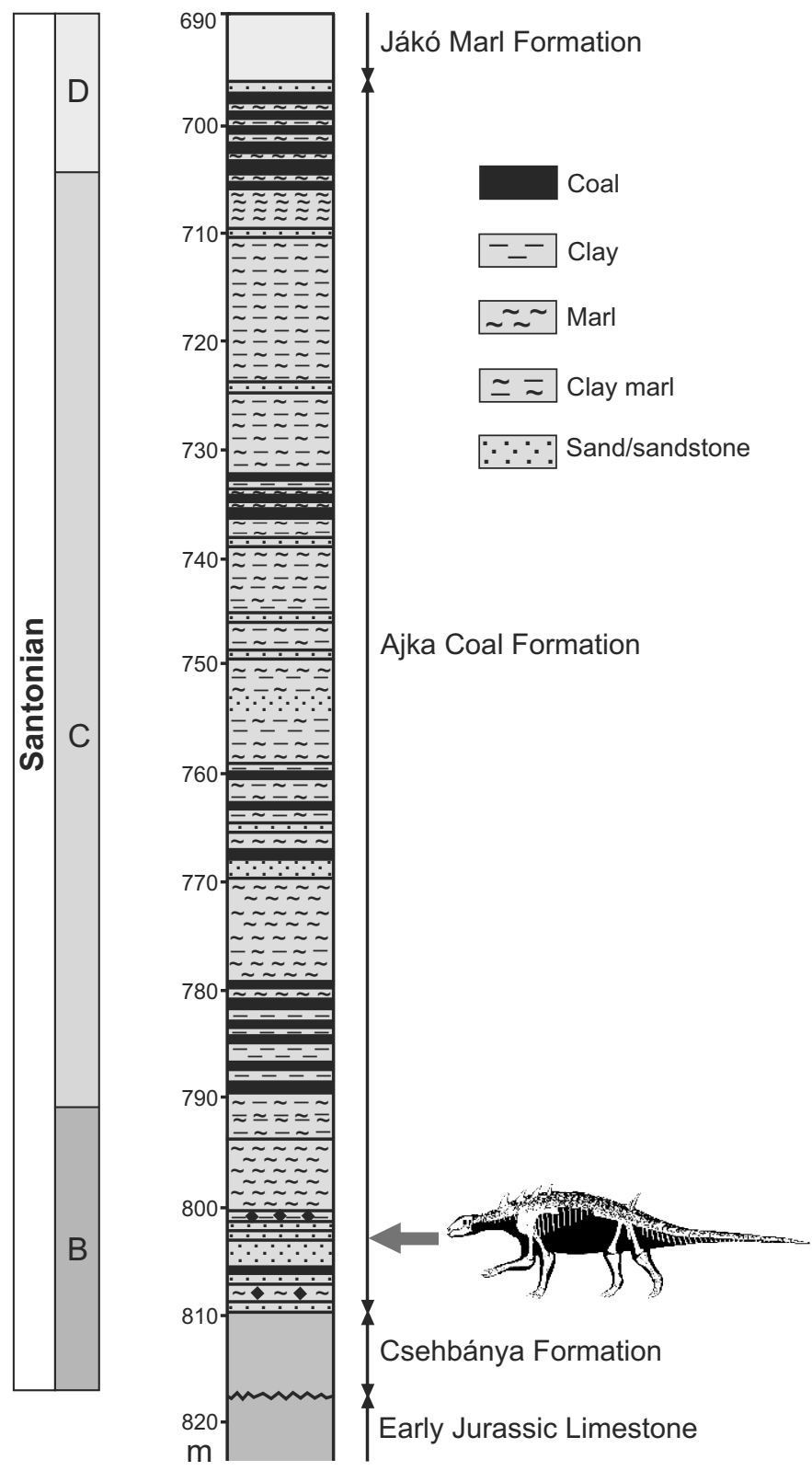




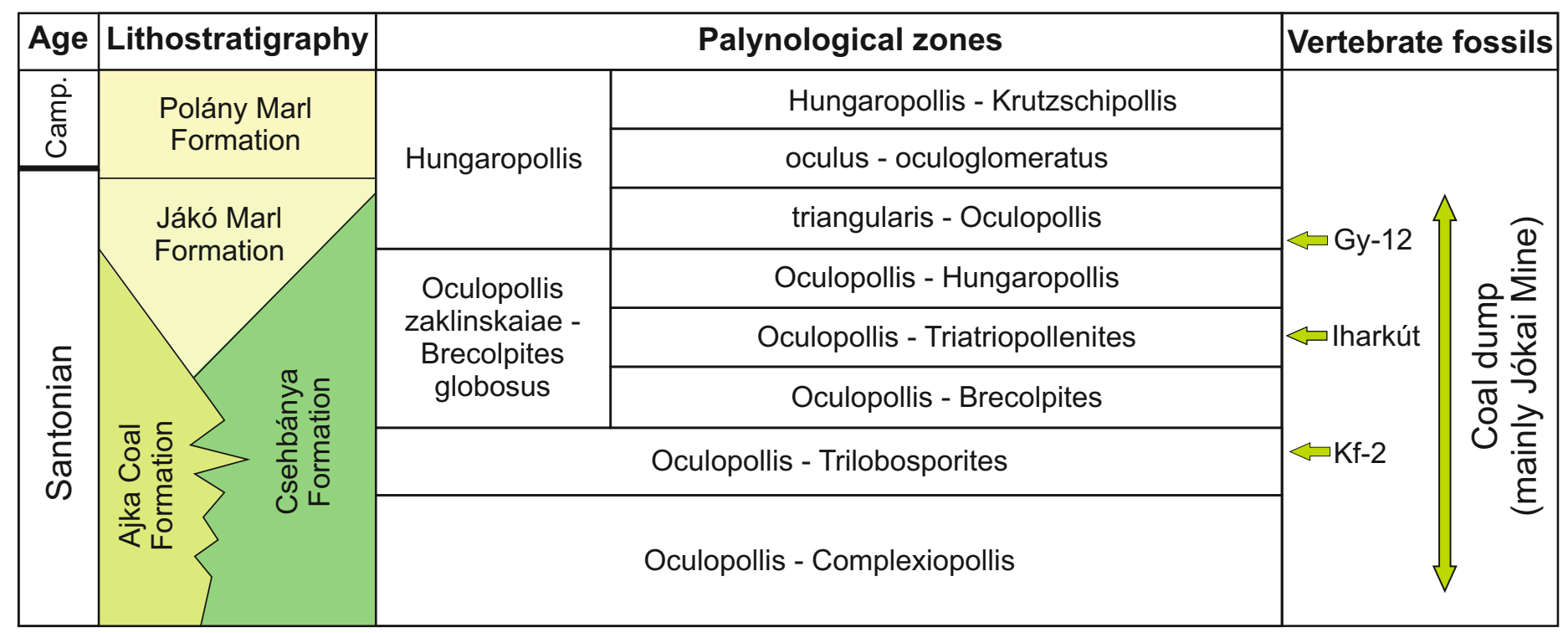




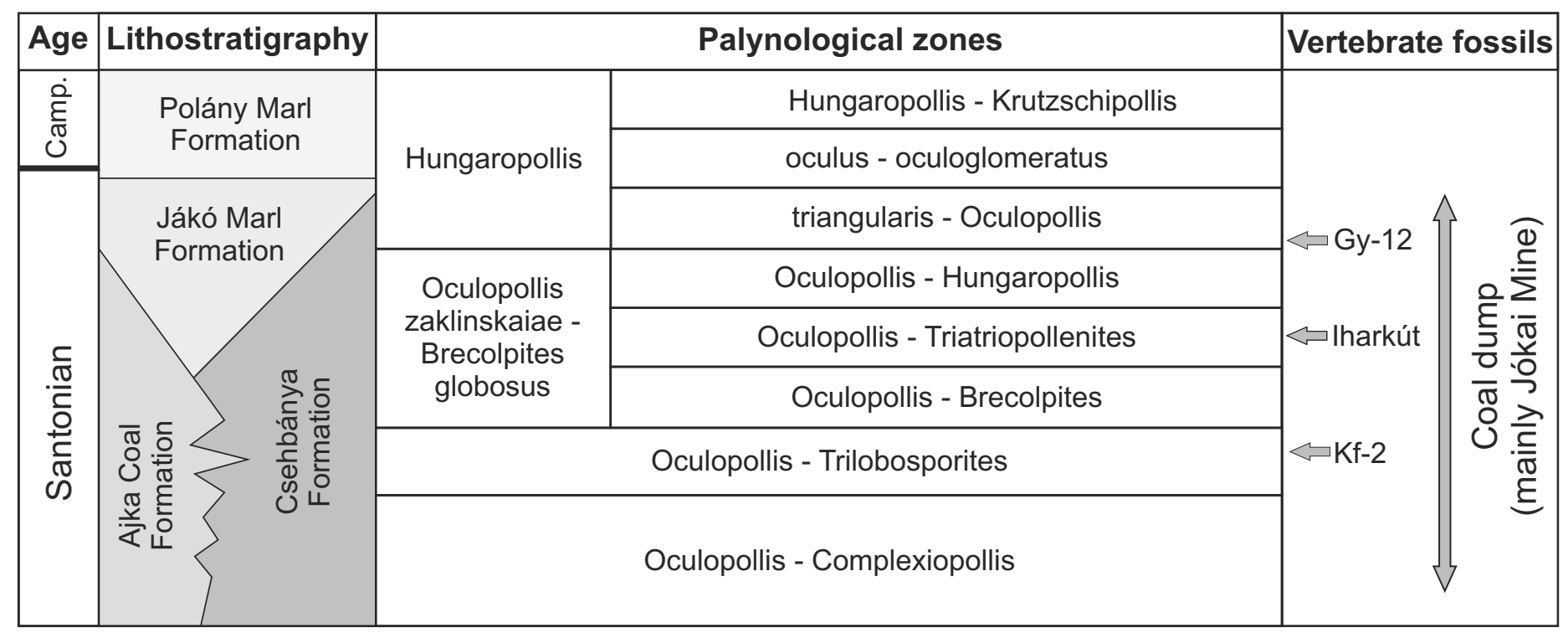


Click here to download high resolution image
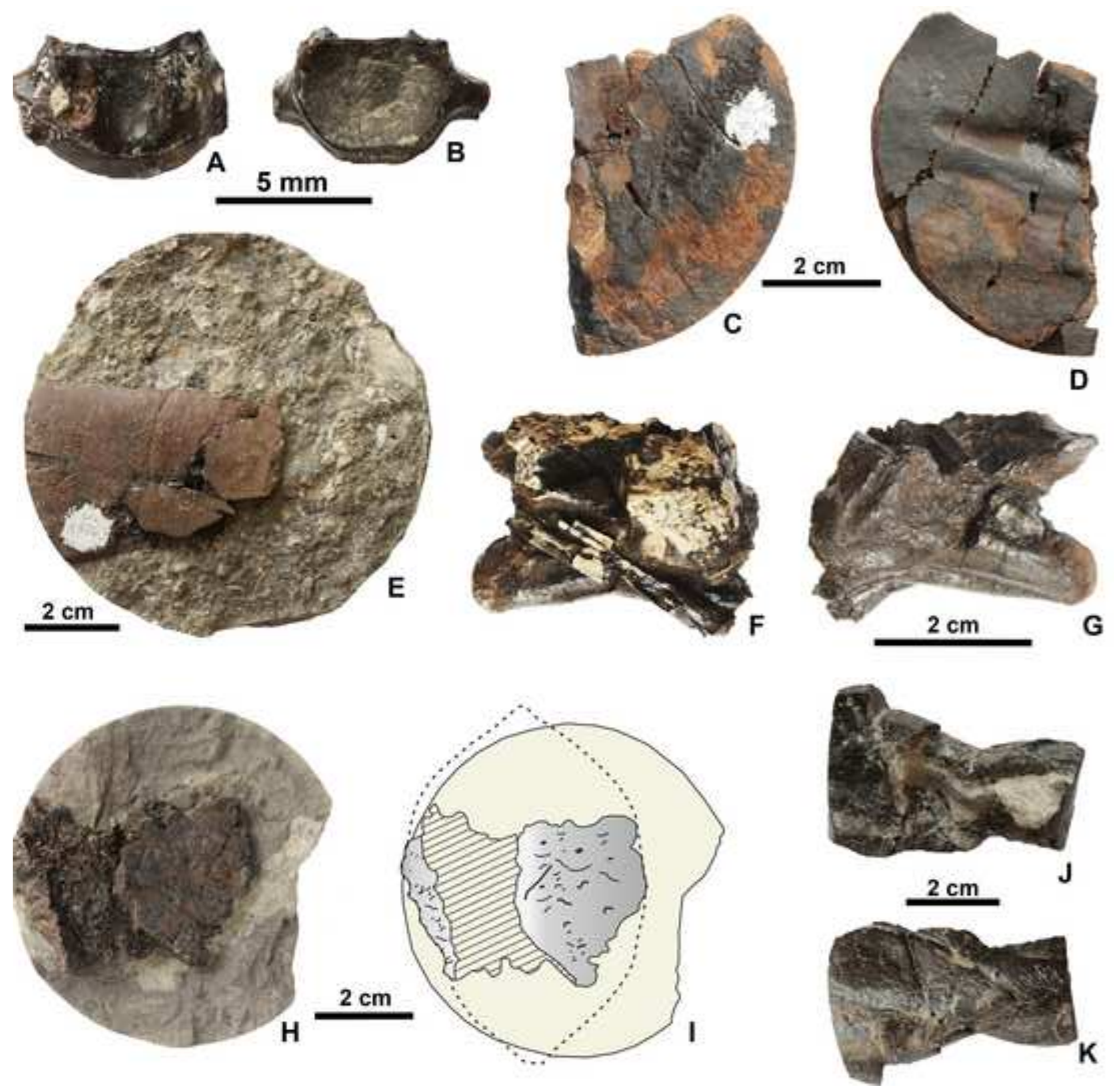
Click here to download high resolution image
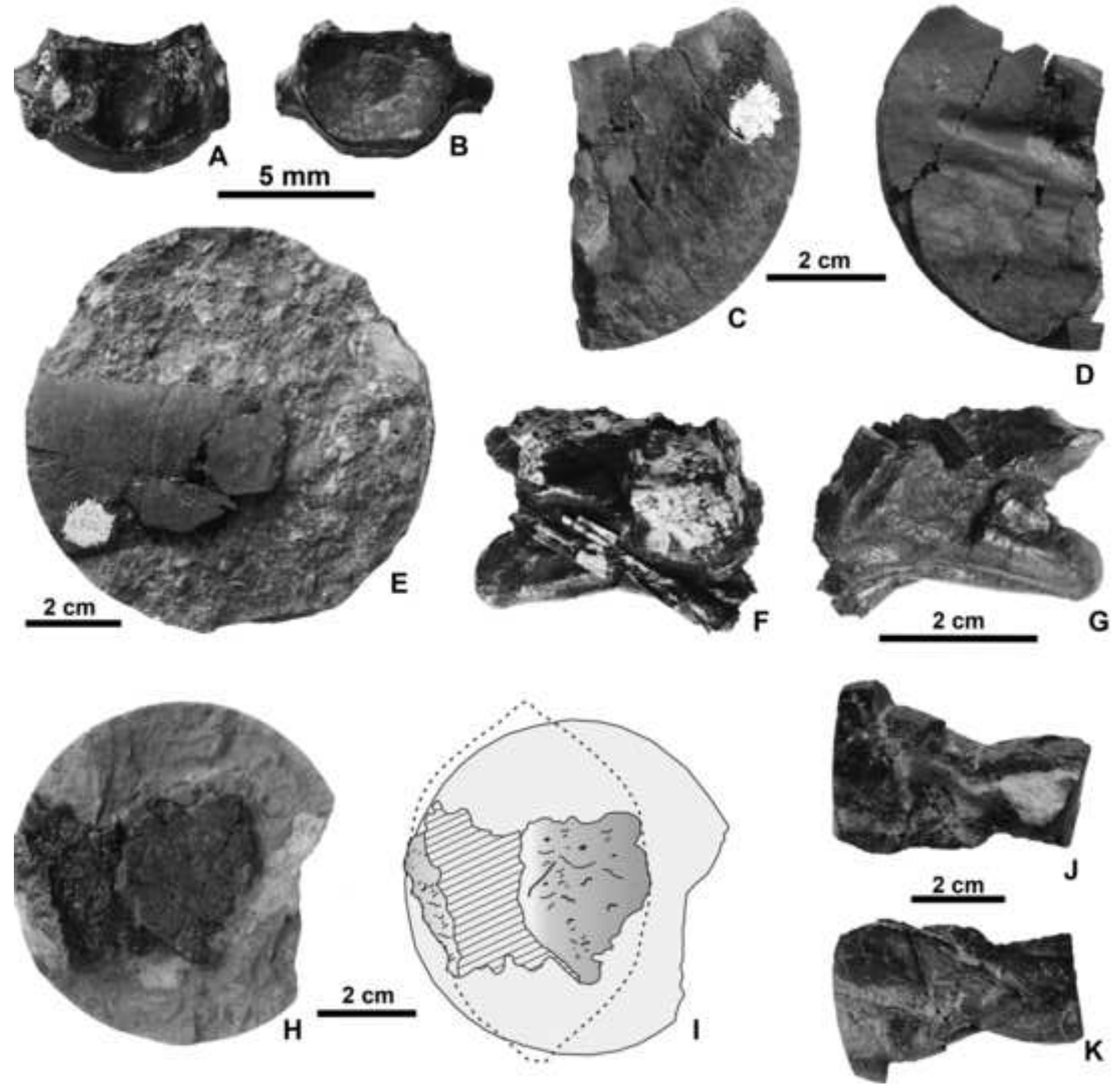
Click here to download high resolution image
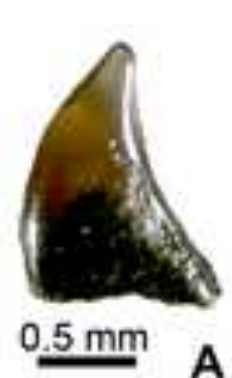

A
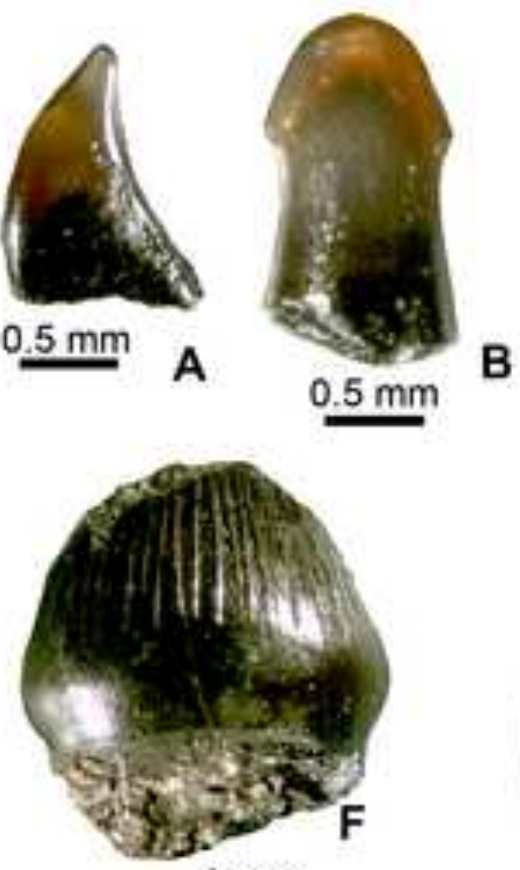

$1 \mathrm{~mm}$
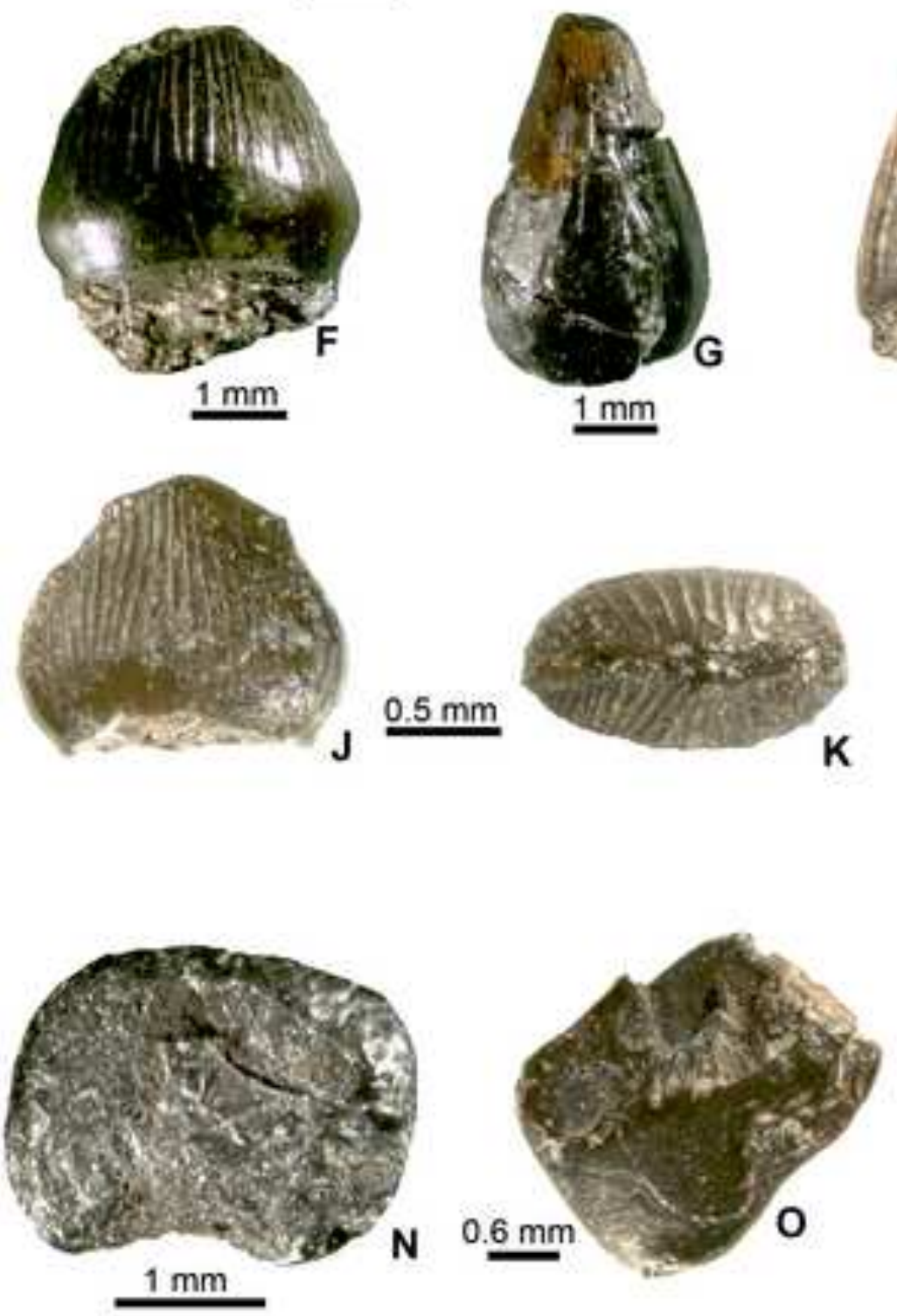
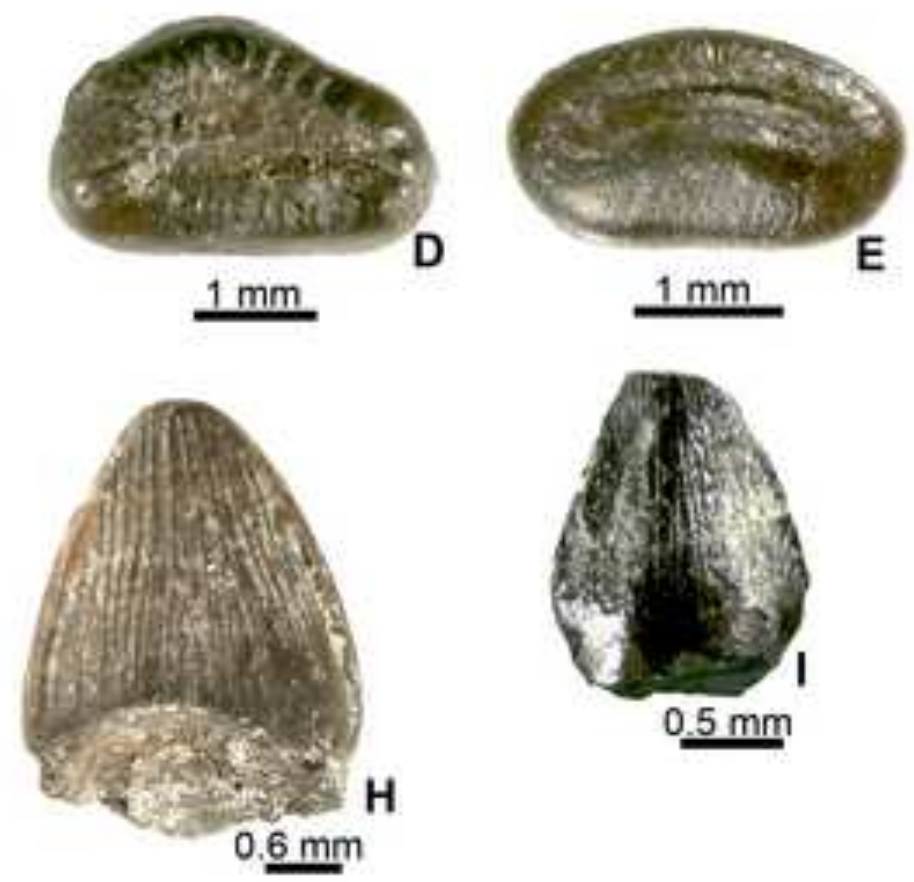
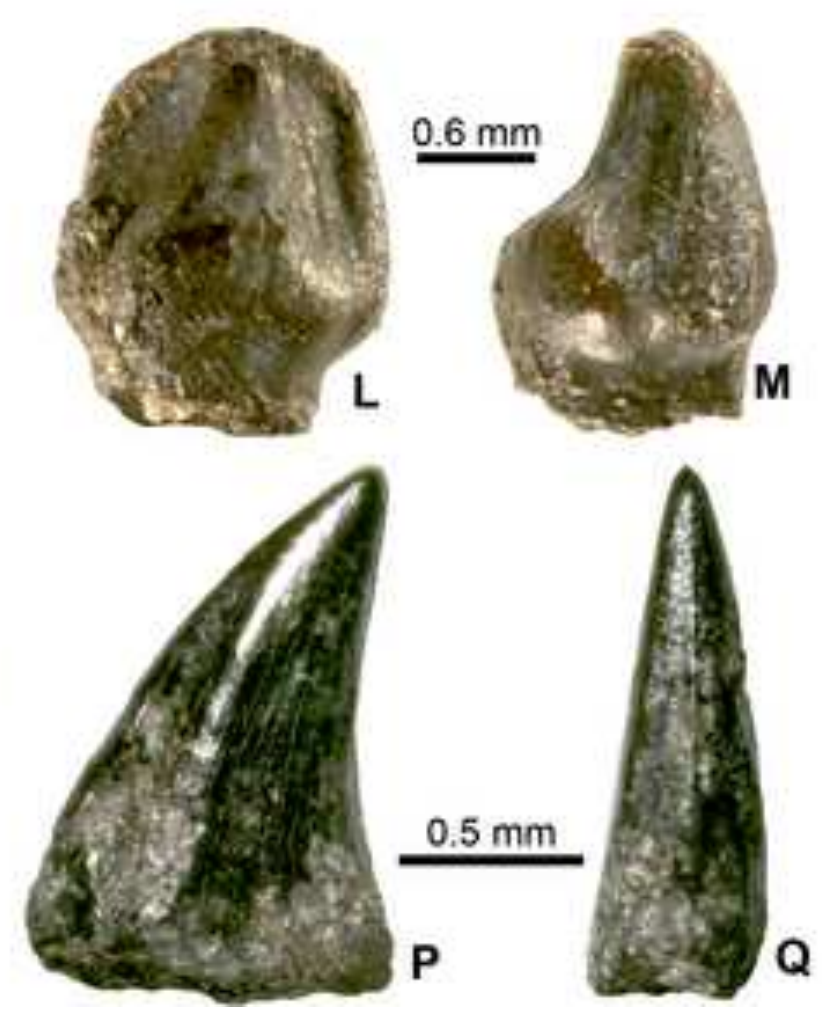
Figure 5 BW

Click here to download high resolution image

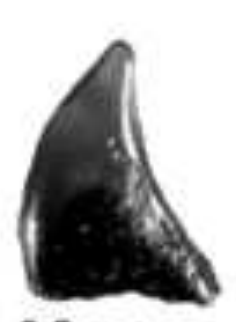

$0.5 \mathrm{~mm} A$
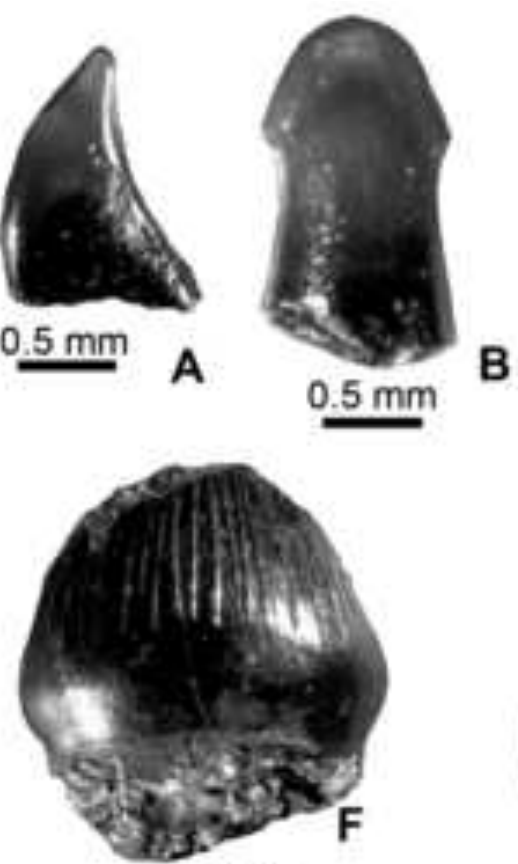

$1 \mathrm{~mm}$
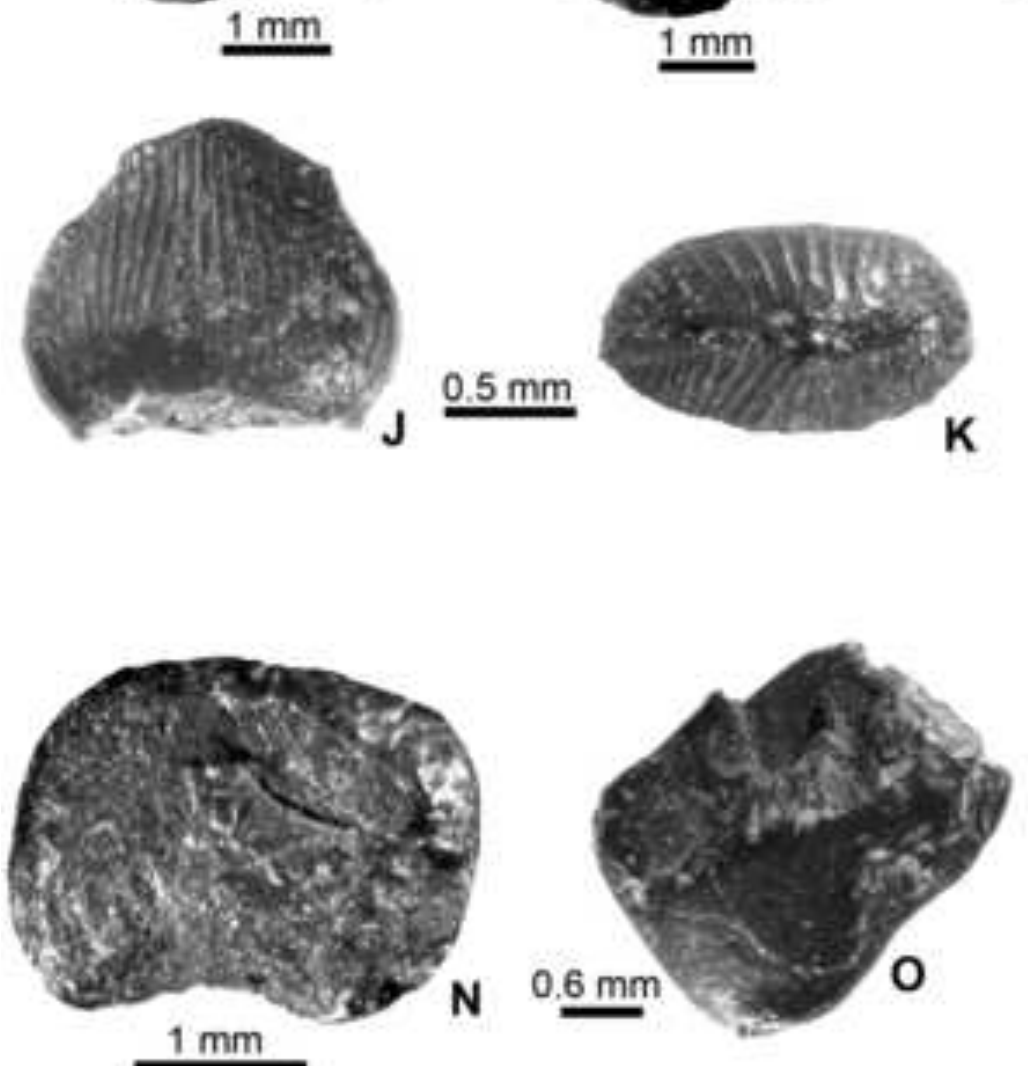
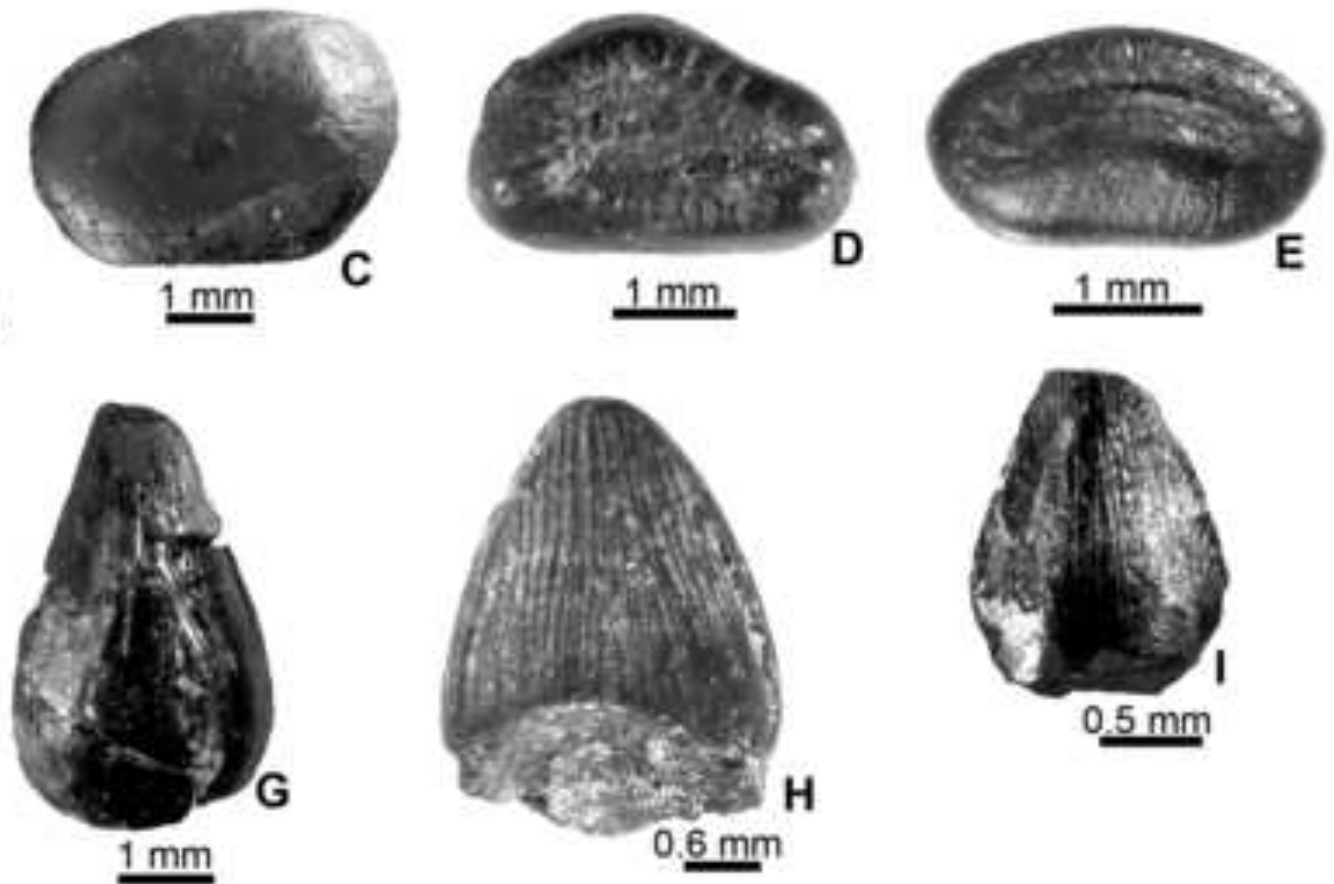
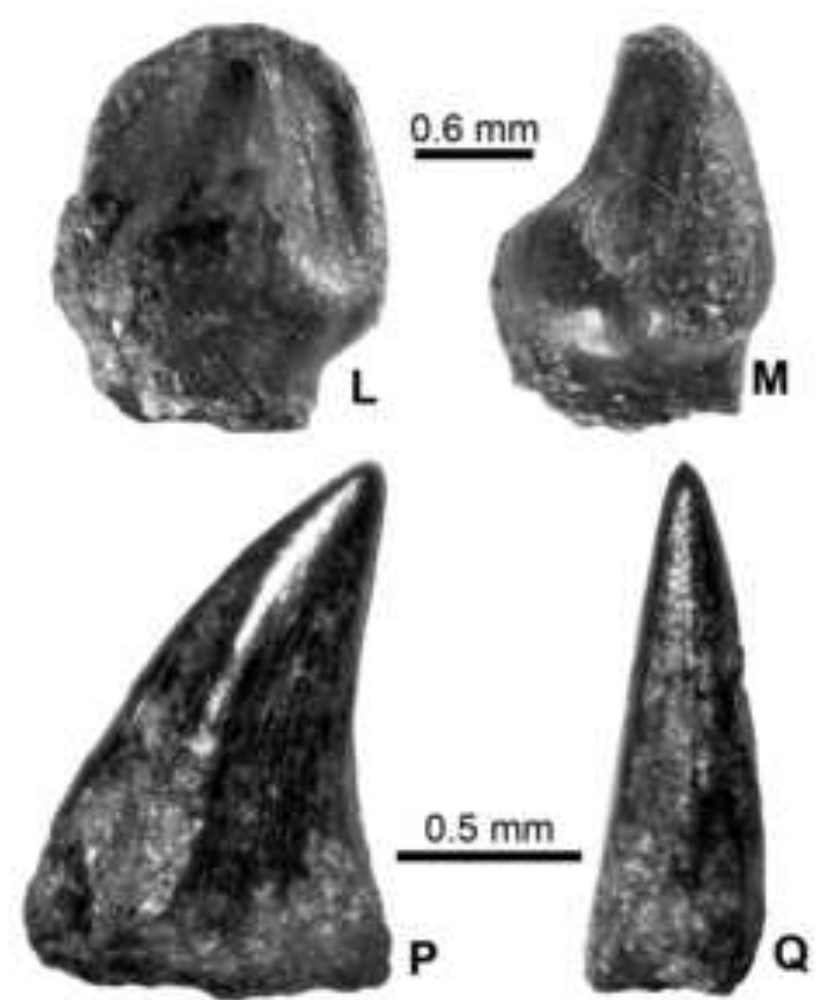